\title{
Targeted Genome Mining Discovery of the Ramoplanin Congener Chersinamycin from the Dynemicin-Producer Micromonospora chersina DSM 44154.
}

\author{
Kelsey T. Morgan ${ }^{\dagger}$, Jeffrey Zheng ${ }^{\dagger}$, Dewey G. McCafferty ${ }^{\star \dagger}$ \\ ${ }^{\dagger}$ Department of Chemistry, Duke University, Durham, North Carolina 27708, United States \\ ${ }^{\ddagger}$ Department of Biochemistry, Duke University Medical Center, Durham, North Carolina 27708, United States
}

ABSTRACT: The availability of genome sequence data combined with bioinformatic genome mining has accelerated the identification of biosynthetic gene clusters (BGCs). Ramoplanins and enduracidins are lipodepsipeptides produced by Actinoplanes ramoplaninifer ATCC 33076 and Streptomyces fungicidicus B-5477, respectively, that exhibit excellent in vitro activity against a broad spectrum of Gram-positive pathogens. To explore if ramoplanin/enduracidin-like BGCs exist within genomes of organisms sequenced to date, we devised a targeted genome mining strategy that employed structure-activity relationships to identify conserved, essential biosynthesis genes from the ramoplanin and enduracidin BGCs. Five microorganisms were found to contain ramoplanin-like BGCs: the enediyne antibiotic producer Micromonospora chersina strain DSM 44151(dynemycin); the glycopeptide antibiotic producers Amycolatopsis orientalis strain B-37 (norvancomycin), Amycolatopsis orientalis strain DSM 40040 (vancomycin), and Amycolatopsis balhimycina FH1894 strain DSM 44591 (balhimycin); and Streptomyces sp. TLI_053. A single compound from fermentation of $M$. chersina was purified to homogeneity and found to possess good antibiotic activity against several Gram-positive bacterial test strains $(1-2 \mu \mathrm{g} / \mathrm{mL})$, comparing favorably to ramoplanin family members. We named this compound chersinamycin and elucidated its covalent structure, which differs distinctly from ramoplanins and enduracidins. Further, the chersinamycin BGC was validated through insertional gene inactivation using CRISPR-Cas9 gene editing. In addition to the information gained by comparing and contrasting the sequence and organization of these five new BGCs, the amenability of $M$. chersina to genetic manipulation provides a muchneeded tool to investigate the fundamental aspects of lipodepsipeptide biosynthesis and to facilitate metabolic engineering efforts for the production of novel antibiotics capable of combating antibiotic-resistant infections. 
bioRxiv preprint doi: https://doi.org/10.1101/2020.05.22.111625; this version posted May 25, 2020. The copyright holder for this preprint (which was not certified by peer review) is the author/funder, who has granted bioRxiv a license to display the preprint in perpetuity. It is made available under ACC-BY-NC-ND 4.0 International license.

\section{INTRODUCTION}

For decades antimicrobial chemotherapy has been utilized successfully for the treatment of infectious disease. However, over the past thirty years, the rate of introduction of new-in-class antibiotics has flattened while the rate of clinical cases of infections due to bacteria that are resistant to front-line antibiotics has steadily increased, thus signaling a pressing need for the discovery and development of new antibiotic therapeutics.

Historically, natural products have helped meet this unmet need by providing a rich source of antimicrobial leads, as almost $70 \%$ of clinically approved antibiotics are natural products or second-generation natural product derivatives. ${ }^{1}$ For example, the glycopeptide antibiotics vancomycin and teicoplanin are first-generation natural products that have efficacy in their native form against infections from Gram-positive pathogens. Unfortunately, however, many first-generation natural products that possess good antimicrobial activity in vitro fail to make the jump to drug candidates because of several possible limitations: low stability, poor absorption, high toxicity, limited routes of delivery, and/or propensity to encounter resistance mechanisms. This creates a paradox in which these liabilities can preclude further investments in second-generation versions that could help overcome initial limitations, as exemplified by second-generation semisynthetic glycopeptides such as telavancin, oritavancin, and dalbavancin that exhibit markedly improved pharmacological properties and reduced toxicity profiles over the parent natural products. ${ }^{2,3}$

The ramoplanins are an exciting family of first-generation natural products that possess excellent in vitro activity against a wide range of Gram-positive bacteria. The family is composed of nonribosomally biosynthesized lipodepsipeptides that fall into two subclasses based on structure, the ramoplanins and the enduracidins (Figure 1). Ramoplanins, first isolated in 1984 by fermentation of Actinoplanes ATCC 33076, 4,5 are a mixture of six lipoglycodepsipeptides of which factor A2 is most abundant, though all isomers possess similar antibiotic activities. ${ }^{6,7}$ The enduracidins A and B, lipodepsipeptides produced by Streptomyces fungicidicus B5477, ${ }^{8-10}$ are not glycosylated and contain longer $\mathrm{N}$-terminal fatty acyl tails yet exhibit similar activity to ramoplanin. This antibiotic activity results from inhibition of bacterial cell wall biosynthesis. Ramoplanins and enduracidins capture peptidoglycan (PG) biosynthesis intermediate Lipid II, the substrate for transglycosylase and transpeptidase enzymes. Sequestering this late stage intermediate prevents formation of the mature, fully crosslinked peptidoglycan, resulting in a mechanically weakened cell wall and bacterial death due to osmotic lysis. ${ }^{9,10}$ In addition to interruption of PG biosynthesis, it has been reported that exposure of $S$. aureus to bactericidal concentrations of ramoplanin A2 results in membrane depolarization, suggesting a complementary mode of action through disruption of lipid membrane integrity. ${ }^{11}$

Ramoplanin A2 gained initial interest for treatment of Gram-positive bacterial infections that are resistant to antibiotics such as glycopeptides, macrolides, and penicillins. ${ }^{9,12-15}$ It has excellent in vitro activity with MICs ranging from $0.125-2 \mu \mathrm{g} / \mathrm{mL}$. Unfortunately, this first-generation natural product could stand to be improved because it is not orally absorbed, is mild to moderately hemolytic when delivered intravenously, and its macrolactone is susceptible to 
bioRxiv preprint doi: https://doi.org/10.1101/2020.05.22.111625; this version posted May 25, 2020. The copyright holder for this preprint (which was not certified by peer review) is the author/funder, who has granted bioRxiv a license to display the preprint in perpetuity. It is made available under aCC-BY-NC-ND 4.0 International license.

hydrolysis when administered by intraperitoneal injection. ${ }^{16}$ Enduracidins $A$ and $B$ have a similar activity profiles, but exhibit reduced solubility and have been approved only for use outside of the United States as a growth-promoting feed additive for livestock. ${ }^{17,18}$

Despite minor limitations, ramoplanin was recently FDA approved for the treatment of Clostridium difficile colonic infections (CDI) and associated diarrhea. ${ }^{19-22}$ Oral delivery of ramoplanin achieves high colonic concentrations (>300 $\mu \mathrm{g} / \mathrm{mL}$ ), which far exceeds MICs determined in vitro against vancomycin-susceptible and vancomycin-resistant C. difficile strains $(0.25-0.50 \mu \mathrm{g} / \mathrm{mL})$. As such, the ramoplanin family of antibiotics remains a promising antibacterial agent warranting further development to broaden its therapeutic potential.

One underexplored avenue to develop second generation ramoplanin family members is to identify naturally produced congeners that may possess favorable structural diversities or allow for biosynthetic manipulations. In the case of glycopeptides, the development of second generation therapeutics has benefited from an arsenal of natural sources for investigation and development - there are over 30 glycopeptide-producing organisms giving rise to different core scaffolds and peripheral modifications such as acylation, glycosylation, and methylation that have provided insight into mode of action and been used to prioritize semisynthetic derivatization. ${ }^{2,3}$ Two recent studies have suggested the ramoplanin family of antibiotics are more widespread than previously assumed as well, and thus support such a strategy for accessing novel derivatives. First, during an unbiased screen of microbial extracts for activation of LiaRS reporter strains, de la Cruz and coworkers discovered 49 uncharacterized actinomycetes strains that produce compounds resembling ramoplanin A2 or ramoplanin analogs by LC/MS analyses. ${ }^{23}$ Independently, a second piece of evidence to this conclusion can be inferred from the recent work of $\mathrm{Li}$ and coworkers, who reported that enduracidin was produced by a second actinomycetes strain, Streptomyces atrovirens MGR140. ${ }^{24}$ These studies suggest that strains besides Actinoplanes and S. fungicidicus harbor biosynthetic machinery for ramoplanin congener production, and that new producing organisms could be uncovered to expand this important antibiotic class. As large scale sequencing efforts in recent years have generated a wealth of genomic data that can be mined with bioinformatics to identify biosynthetic gene clusters (BGCs) ${ }^{25}$ we envisioned that a genome mining approach could be used to identify new ramoplanin family producers.

In this study we developed a systematic method for uncovering ramoplanin-like BGCs within sequenced bacterial genomes. Previous structure activity relationship (SAR) studies of Reynolds, Boger, Walker, Ciabatti, and McCafferty groups were used to identify functionally important regions within the ramoplanin and enduracidin nonribosomal peptide synthetases (NRPSs) and associated BGC standalone enzymes to serve as a suite of key sequence probes for genome mining. ${ }^{15,16,26-35}$ Using these SAR-informed protein sequences as search queries, we quickly developed a workflow that identified bacterial strains containing new lipodepsipeptide BGCs (Figure 2A). Herein we report the discovery of complete biosynthetic pathways for a ramoplanin family antibiotic in five new bacterial strains. 
bioRxiv preprint doi: https://doi.org/10.1101/2020.05.22.111625; this version posted May 25, 2020. The copyright holder for this preprint (which was not certified by peer review) is the author/funder, who has granted bioRxiv a license to display the preprint in perpetuity. It is made available under aCC-BY-NC-ND 4.0 International license.

Four of these five strains are host producers of either enediyne or glycopeptide antibiotics. One of these representative strains, the dynemicin producer Micromonospora chersina DSM 44154, was found to produce a ramoplanin congener we termed chersinamycin (Figure 2B). We report here the isolation, structure elucidation, antimicrobial activity, and validation of the BGC function using CRISPR-Cas9 gene editing of chersinamycin. These findings provide the foundation to further broaden our understanding of structure-function relationships among the ramoplanin family, to decode the molecular logic of ramoplanin biosynthesis, and to lay the groundwork for production of improved second generation ramoplanin analogs through mutasynthesis and metabolic engineering.

\section{RESULTS AND DISCUSSION}

Examination of structure-activity analyses to inform genome mining rationale. The search for new ramoplanin family lipodepsipeptide gene clusters began with genome mining for key biosynthetic proteins linked to functionally important structural features, a process that was unique in that it was guided by results from structurefunction studies of ramoplanins and enduracidins. ${ }^{8-10,15,16,30-47}$ There are several shared structural features of these antibiotics that are critically important for their activity: (1) Conserved amino acid type and stereochemistry within the 17-residue depsipeptide, which influences the overall peptide receptor-like conformation, ${ }^{8,31,36,41}$ promotes antibiotic dimerization, ${ }^{31,37,47}$ and facilitates binding to its lipid II target; ${ }^{9,15,34,35}$ (2) Conformational constraint imparted by the 49atom macrocycle ${ }^{30,32-35,42,45}$ and (3) $\mathrm{N}$-terminal acylation, which promotes bacterial membrane association and influences its amphipathic $\mathrm{C} 2$ symmetrical dimeric conformation that is adopted upon membrane binding. ${ }^{31,36}$

Common to the ramoplanin and enduracidin BGCs are four NRPSs termed Ramo/End A-D (Figure 1A), which encode enzymes responsible for assembly line synthesis of these 17-residue peptides, including 12 nonstandard amino acids and seven with a D-amino acid configuration. Three large NRPS ORFs $(A, B, C)$ appear to be organized in accordance with the collinearity rule of modular construction of NRPS condensation, adenylation, and thiolation domains. The exception is ramoD/endD, which encodes a standalone adenylation/thiolation di-domain enzyme that is predicted to work in trans with the NRPS B dual condensation/epimerization (C/E) domain to introduce D-allo-Thr ${ }^{8}$ within the linear peptide sequence.

Within the primary sequences of ramoplanin and enduracidin, there are several conserved residues that have been strongly linked to lipid II binding affinity and antibiotic activity. Boger and colleagues elegantly employed total solution-phase synthesis to perform an alanine scan of ramoplanin residues 3-13, 15, and 17 within [Dap ${ }^{2}$-ramoplanin A2 aglycon, a hydrolytically stable ramoplanin aglycon analog. ${ }^{30,32,34}$ When compared to ramoplanin A1-A3 complex $(\mathrm{MIC}=0.19 \mu \mathrm{g} / \mathrm{mL})$, ramoplanin A2 aglycon $(\mathrm{MIC}=0.11 \mu \mathrm{g} / \mathrm{mL})$, and [Dap $\left.{ }^{2}\right]$-ramoplanin aglycon $(\mathrm{MIC}=0.07 \mu \mathrm{g} / \mathrm{mL})$, alanine substitution of these 12 positions resulted in MIC increases over the parent antibiotics ranging from 1.3 to 540 fold (Figure 1B). Three positions exhibited markedly increased MICs: D-Hpg ${ }^{3}$ (74-fold), D-Hpg ${ }^{7}$ (53-fold) and D-Orn ${ }^{10}$ (540-fold). Residue 7 lies within the D-allo-Thr $-\mathrm{Hpg}^{6}-\mathrm{D}-\mathrm{Hpg}^{7}-\mathrm{D}-\mathrm{allO}-\mathrm{Thr}^{8}$ sequence that is conserved with enduracidins, 
bioRxiv preprint doi: https://doi.org/10.1101/2020.05.22.111625; this version posted May 25, 2020. The copyright holder for this preprint (which was not certified by peer review) is the author/funder, who has granted bioRxiv a license to display the preprint in perpetuity. It is made available under aCC-BY-NC-ND 4.0 International license.

and residue 10 is functionally conserved in enduracidins as D-enduracididine (End). Subsequently, Boger, Walker, and coworkers determined the effect of alanine substitution on lipid II binding and penicillin binding protein inhibition using a $\left[\mathrm{Dap}^{2}\right]$-ramoplanin A2 amide scaffold that was modified by the inclusion of single alanines along positions $3-12^{30,32}$ The introduction of Ala residues increased $K_{d}$ values ranging from $378-8700 \mathrm{nM}$, with positions 4 , 8, and $10-12$ exhibiting $>100$-fold increased $K_{d}$. Analogs that exhibited the most significant changes in MIC and $K_{d}$ values were considered functionally important and therefore likely to be conserved within a new ramoplanin/enduracidin congener. As such, these regions were carefully considered when devising our genome mining strategy.

The impact of conformational constraint imparted by the macrocycle was first investigated by Williams and coworkers, who demonstrated that hydrolysis of the macrolactone bond of ramoplanose resulted in a markedly less soluble linear peptide that lacked antimicrobial activity. ${ }^{42}$ In addition, Boger and coworkers showed that ramoplanin A2 activity required a 49-membered macrocycle, regardless of whether the macrocycle was linked by a lactone or lactam bond. ${ }^{34}$ Within Ramo C/End C NRPSs, the C-terminal thioesterase domain is responsible for installing this indispensable macrocycle ${ }^{28,29}$ and was considered a key biosynthetic sequence to be included as a genome mining search query.

Ramoplanins and enduracidins share genes that encode enzymes for fatty acid activation and lipoinitiation, the modification essential for bacterial membrane binding and antimicrobial activity. ${ }^{28,29}$ Both BGCs lack candidate ORFs encoding enzymes for de novo fatty acid biosynthesis, so it is likely that these fatty acids originate from primary metabolism and are activated as free fatty acids. ${ }^{29,44}$ In support of this hypothesis, an acyl carrier protein (ACP) and a fatty acid adenylate forming ligase (FAAL) appear in both BGCs. The presence of an N-terminal $\mathrm{C}^{\text {III }}$ condensation domain in NRPS A of both BGCs further supports a lipoinitiation mechanism involving fatty acid activation and condensation with residue one to form the starting $\mathrm{N}$-acyl amino acid starter unit.

Although both antibiotic BGCs contain conserved acyl-CoA dehydrogenases (ACADs) and oxidoreductases that are believed to install the $E, Z$ fatty acid double bonds, these enzymes are likely non-essential, since loss of these double bonds by hydrogenation of ramoplanin $A 2^{48}$ or semisynthesis ${ }^{16}$ resulted in no significant reduction in antimicrobial activity. Similarly, mannosylation ${ }^{39,40}$ and chlorination ${ }^{43,49,50}$ are structural elements that have been shown to be nonessential for antibiotic activity, although mannosylation has been shown by our group to enhance the conformational stability of ramoplanin $\mathrm{A} 2^{26,38}$ and improve solubility over enduracidin. ${ }^{37}$

Collectively, these studies link membrane association, antimicrobial activity, and lipid II binding with specific structural elements shared between ramoplanin and enduracidin. By correlating functionally important architectural features with corresponding BGC-encoded enzymes that are responsible for their assembly, we identified a suite of probes for genome mining to search for new ramoplanin congeners. 
bioRxiv preprint doi: https://doi.org/10.1101/2020.05.22.111625; this version posted May 25, 2020. The copyright holder for this preprint (which was not certified by peer review) is the author/funder, who has granted bioRxiv a license to display the preprint in perpetuity. It is made available under aCC-BY-NC-ND 4.0 International license.

Discovery of ramoplanin-like biosynthetic gene clusters by genome mining. BGC sequences of seven SAR-guided probes from the NRPSs A-D, ACPs, and FAALs from the ramoplanin and enduracidin BGCs were used as initial BLASTp search queries to identify homologs from bacterial strains within the NCBI database. Protein sequence hits with $>50 \%$ identity to the search queries were collected and cross-referenced to microbial strains that met the criteria of containing at least 4 homologs within its genome, regardless of ORF location. With these initial boundary conditions, 13 microbial strains were identified (Table S1). To determine if the protein homologs from the 13 strains were organized into a single BGC, we expanded the sequence analysis. Given the importance of the primary sequence encoded by the Ramo B/End B NRPS to the activity of ramoplanin and enduracidin, we analyzed the translated sequences within forty ORFs on either side of each NRPS B hit. Sequences obtained from the NCBI protein database were submitted to the EFI-Enzyme Similarity $\mathrm{Too}^{54}$ for an all vs. all Blast search and assembly into a sequence similarity network (SSN) (Figure S1).

The SSN revealed clear protein clusters representing nearly all proteins within the defined ramoplanin and enduracidin BGCs; only five of the 24 proteins in the enduracidin $\mathrm{BGC}^{32}$ and six of the 31 proteins in the ramoplanin $\mathrm{BGC}^{31}$ are represented as isolated nodes. Though multiple proteins from each of the 13 preliminary strains were present within these clusters, we found that five strains contained all seven of the proteins utilized as genome mining probes localized to a single region of the genome. In addition, within the analyzed region of each of these five strains a significant number of ORFs were homologous to ramoplanin and enduracidin ORFs involved in nonproteinogenic amino acid synthesis, transcriptional regulation, and natural product transport. The strains found to encode a putative BGC for ramoplanin/enduracidin congener production include Micronomonospora chersina strain DSM 44151, Amycolatopsis orientalis strain B-37, Amycolatopsis orientalis strain DSM 40040, Amycolaptopsis balhimycina FH1894 strain DSM 44591, and Streptomyces sp. TLI_053 (Figure 3). Remarkably, four of these five new BGCs reside within bacterial strains that have been cultured and extracted for previously characterized natural products, including $A$. orientalis strain DSM 40040 and $A$. balhimycina FH1894, which produce the glycopeptide antibiotics vancomycin ${ }^{52}$ and balhimycin, ${ }^{53}$ respectively, and $M$. chersina DSM 44151, which produces the enediyne antibiotic dynemicin. ${ }^{54}$

The bounds of each of the five new BGCs were determined by analyzing clustered proteins within the SSN (Figure 3, Figure S2A). We identified remarkable similarity between ORFs included within the BGCs from each strain. The absence of clustered proteins not found within ramoplanin and enduracidin BGCs supports the previously defined bounds of the ramoplanin and enduracidin clusters. ${ }^{28,29}$ The gene organization and degree of conservation between each BGC likely reflects the necessity of nearly every protein in the cluster.

The SAR-guided genome mining approach allowed for the identification of five complete BGCs with strong similarity to the ramoplanin/enduracidin BGCs, suggesting that these five microorganisms contain the biosynthetic machinery to produce ramoplanin-like compounds. Manual analyses of increasingly stringent search criteria had the advantage of identifying candidates with inverted or varied organization of ORFs within the cluster, making them unable 
bioRxiv preprint doi: https://doi.org/10.1101/2020.05.22.111625; this version posted May 25, 2020. The copyright holder for this preprint (which

was not certified by peer review) is the author/funder, who has granted bioRxiv a license to display the preprint in perpetuity. It is made available under aCC-BY-NC-ND 4.0 International license.

to be predicted by algorithms used by programs such as antiSMASH ${ }^{55}$ This method was advantageous because it quickly allowed the selection criteria for hits to be filtered to select those most likely to belong to the desired antimicrobial class.

In silico analysis of the NRPSs. Each of the five BGCs contained four NRPSs that are predicted to incorporate 17 amino acids into the peptide (Figure S2B). The organization of the NRPSs within each BGC was very similar to the ramoplanin and enduracidin NRPSs, including the presence of a standalone A-T domain of NRPS D, which suggests that these NRPSs also operate in trans with module 6 of each NRPS B that contains only C and T domains. NRPS A from each new cluster contains two full modules for the incorporation of two amino acids, leaving Ramo $A$ as a unique NRPS in which a single module is predicted to act in an iterative fashion to assemble the first two asparagine residues.

The linear peptide sequence from each cluster was predicted from the adenylation domain specificityconferring sequences. ${ }^{56,57}$ Web-based prediction software including NRPSPredictor2 ${ }^{58}$ and the PKS/NRPS Analysis Web Site ${ }^{59}$ was complemented with manual sequence alignment of the eight conserved adenylation domain active site residues to account for genus-dependent sequence variation as well as a lack of predictive power for some unnatural amino acids by web-based software (Table S3, Figure S2B). For each organism, the NRPS-encoded primary sequences clearly predicted that all were likely ramoplanin congeners, yet each predicted sequence was unique and not identical to enduracidin or ramoplanin. Despite these differences, the NRPSs exhibited nearly identical conservation of five "hot spot" residues $\left(\mathrm{Orn}^{4}, \mathrm{Thr}^{8}, \mathrm{Orn}^{10}, \mathrm{Hpg}^{11}\right.$, and $\mathrm{Thr}^{12}$ ) that had been identified as functionally important in ramoplanin for lipid II binding and antimicrobial activity. The only exception is residue 4 of the product encoded by the Streptomyces sp. TLI_053 NRPS, which predicts the ornithine is shifted to residue position 5 (Figure S2B).

Condensation domain sequences within the NRPSs were also examined using antiSMASH predictions and manual sequence alignment to identify C-domain subtypes (Figure S3). ${ }^{60}$ We found that each of the five organisms share a conserved starter condensation domain $\left(\mathrm{C}^{\mathrm{III}}\right)$ as the first domain of NRPS A for fatty acid incorporation at the Nterminal residue, consistent with the presence of a FAAL and ACP within the BGC and necessity of N-acylation for activity of ramoplanin and enduracidin. The order of classical ${ }^{\mathrm{L}} \mathrm{C}_{\mathrm{L}}$ and dual $\mathrm{C} / \mathrm{E}$ domains, responsible for incorporating $\mathrm{L}-$ and D-amino acids, respectively, exactly matches those found in the ramoplanin and enduracidin NRPSs within every module from the five new clusters (with D-amino acids in positions $3,4,5,7,8,10,12$, and 16), with a single exception at NRPS A-module 2 of M. chersina and Streptomyces sp. TLI_053 NRPS A (Figures S2B and S3).

Screening new bacterial strains for ramoplanin congener production. In an effort to identify and isolate new ramoplanin congeners, the three strains $M$. chersina strain DSM 44151, $A$. orientalis strain DSM 40040, and $A$. balhimycina FH 1894 strain DSM 44591 were examined for production of ramoplanin-like molecules. Initial media formulations screened included the optimized media for ramoplanin and enduracidin production, ${ }^{44,61}$ as well as the 
bioRxiv preprint doi: https://doi.org/10.1101/2020.05.22.111625; this version posted May 25, 2020. The copyright holder for this preprint (which was not certified by peer review) is the author/funder, who has granted bioRxiv a license to display the preprint in perpetuity. It is made available under aCC-BY-NC-ND 4.0 International license.

media optimized for production of each strain's predominant natural product. ${ }^{54,62-64}$ Following incubation at various time intervals, cultures were extracted and screened by MALDI-TOF for a peptide within a mass range chosen based on bioinformatic predictions.

Although ramoplanin-like molecules were not observed to be produced by fermentation of either $A$. orientalis or A. balhimycina, fermentation of $M$. chersina for 12 days in dynemicin production medium $\mathrm{H} 881$ resulted in the production of a compound with a mass of $2574 \mathrm{Da}$ that chromatographed similar to ramoplanin A2. This single compound was purified to homogeneity, generating yields of $1-3 \mathrm{mg} / \mathrm{L}$ (isolated, unoptimized yields). We named this compound chersinamycin and pursued its bioinformatics-guided structure elucidation and evaluation of its antimicrobial activity.

In silico characterization of the chersinamycin BGC. To help reconcile the observed mass of chersinamycin with the predicted structure, we first examined the $M$. chersina strain DSM 44151 BGC, which is composed of 32 genes encoding proteins for transport, transcriptional regulation, amino acid biosynthesis, peptide assembly, and peptide tailoring (Figure 4, Table S7). In addition to the four NRPSs (Chers A-D) that are responsible for the production of a 17 residue linear peptide, the C-terminal thioesterase domain of Chers $\mathrm{C}$ suggests that the peptide is offloaded with concomitant cyclization (Figure 4A, Figure S4). While $\beta$-hydroxylation of the second amino acid, predicted as L-Asn, is difficult to predict based on adenylation domain sequence alone, a putative hydroxylase enzyme (Chers 38) was found in the chersinamycin BGC with high sequence identity to the ramoplanin hydroxylase (Ramo 10). A homologous enzyme is also identified in the Streptomyces sp. TLI_053 cluster, predicted to activate an aspartic acid at residue 2 , but is absent in the additional four clusters which are each predicted to activate threonine at the second position (Table S2). Additionally, high percent identity between thioesterase sequences from the chersinamycin and ramoplanin clusters (Figure S4) suggested the site of macrolactonization to be the same.

Turning to the surrounding chersinamycin biosynthetic machinery, the presence of genes for Hpg biosynthesis (Chers 29, 34, and 59) supports the large number of predicted Hpg residues in the peptide sequence (Figure 4A, Table S7). At residues 4 and 10, the adenylation domain sequence confers specificity for a hydrophilic residue as predicted by NRPSPredictor2 (Table S3). The specificity sequences are nearly identical to those of ramoplanin and enduracidin at these positions, which contain $\mathrm{Orn}^{4}, \mathrm{Orn}^{10}$ and $\mathrm{Orn}^{4}$, End ${ }^{10}$, respectively. A lack of putative End biosynthesis proteins within the chersinamycin cluster led to the prediction of Orn ${ }^{4}$, Orn ${ }^{10}$ for chersinamycin.

Putative polyketide synthase-like (PKS-like) biosynthetic proteins Chers 29-33 with similarity to chalcone synthase and stilbene synthase suggested that chersinamycin may contain the amino acid 3,5-dihydroxyphenylglycine (Dpg). ${ }^{65}$ This amino acid is found within glycopeptides like vancomycin but absent in both ramoplanin and enduracidin. Though this residue was not directly predicted by NRPSPredictor2 or PKS/NRPS Analysis Web Site, an aromatic 
bioRxiv preprint doi: https://doi.org/10.1101/2020.05.22.111625; this version posted May 25, 2020. The copyright holder for this preprint (which was not certified by peer review) is the author/funder, who has granted bioRxiv a license to display the preprint in perpetuity. It is made available under aCC-BY-NC-ND 4.0 International license.

residue was predicted by NRPSPredictor2 at Chers C-m4 (residue 13). We predicted, therefore, that Dpg is incorporated at residue 13, and that Chers C may contain a novel Dpg-activating adenylation domain sequence.

As described previously, $\mathrm{N}$-acylation has been determined essential to the antimicrobial activity of ramoplanin family antibiotics. In addition to the $\mathrm{C}^{\text {III }}$ domain of Chers A, a predicted FAAL (Chers 54) and ACP (Chers 39) are present within the cluster for fatty acid activation and transfer to the first NRPS-bound residue. Notably absent, however, was the prediction of putative ACADs (Figure 4C, Table S2). While an oxidoreductase is present (Chers 22), a lack of these dehydrogenases in the chersinamycin cluster suggests either a different biosynthetic source for an unsaturated lipid, or the incorporation of a saturated lipid.

Additional ORFs within the BGC appear to encode halogenase and glycosyltransferase tailoring enzymes. Chers 49 is homologous to the characterized halogenases found within the ramoplanin and enduracidin BGCs (Ramo 20 and End 30). Genetic knockout and complementation of Ramo 20 and End 30 within their respective clusters demonstrated that these enzymes are responsible for the monochlorination of $\mathrm{Hpg}^{17}$ in ramoplanin and dichlorination of $\mathrm{Hpg}^{13}$ in enduracidin. ${ }^{43,50}$ Identical adenylation domain specificity sequences at these sites and altered halogenation patterns resulting from genetic replacement of End 30 with Ramo 20 in S. fungicidicus suggested that site specificity of halogenation is controlled by the local structural environment of the full peptide, rather than loading of a halogenated residue onto the NRPS. We were therefore unable to confidently predict the location of possible halogenated residues for chersinamycin, but the high sequence similarity of Chers 49 to Ramo 20 and End 30 led us to suspect chlorination of an aromatic residue. Finally, the chersinamycin BGC contains a putative mannosyltransferase, Chers 59 . The ramoplanin mannosyltransferase Ramo 29 has been implicated through genetic knockout and complementation to instill two D-mannose sugars onto the phenolic oxygen of $\mathrm{Hpg}^{11},{ }^{39,49}$ and therefore glycosylation was predicted for chersinamycin as well.

Chersinamycin isolation and structure elucidation. Numerous analytical methods were employed for the full structure elucidation of chersinamycin. HR-LC/MS revealed a $[\mathrm{M}+2 \mathrm{H}]^{2+}$ molecular ion of 1287.0511 , suggesting a molecular formula of $\mathrm{C}_{119} \mathrm{H}_{158} \mathrm{CIN}_{21} \mathrm{O}_{41}$. The peptide macrocycle was determined to be highly base labile, with exposure to $1 \%$ triethylamine in water resulting in hydrolysis $\left([\mathrm{M}+2 \mathrm{H}]^{2+}\right.$ molecular ion 1296.044). This suggested a lactone macrocycle as opposed to a lactam which would remain intact under such weakly basic conditions, supporting our prediction that ring closure occurs at a side chain hydroxyl.

The ${ }^{1} \mathrm{H}-\mathrm{NMR}$ of the cyclic peptide was first examined to assign individual residues. A large number of exchangeable amide protons $(\delta \mathrm{H} 7.0-10.0)$ and signals within the a-proton region $(\delta \mathrm{H} 3.5-7.0)$ were observed, as well as many doublets in the aromatic region consistent with numerous $\mathrm{Hpg}$ residues $(\delta \mathrm{H} 6.0-7.5)$. Analysis of 2D NMR data allowed the assignment of the 17 amino acid residues (Table S4). COSY and TOCSY correlations were used to assign full aliphatic residues, confirming the incorporation of valine, alanine, glycine, threonines and ornithines into the 
bioRxiv preprint doi: https://doi.org/10.1101/2020.05.22.111625; this version posted May 25, 2020. The copyright holder for this preprint (which was not certified by peer review) is the author/funder, who has granted bioRxiv a license to display the preprint in perpetuity. It is made available under aCC-BY-NC-ND 4.0 International license.

peptide. COSY correlations between aromatic resonances in conjunction with NOEs between these resonances and their amide and alpha protons allowed the assignment of full aromatic residues. Two diagnostic singlets at $\delta \mathrm{H} 6.04$ and $\delta \mathrm{H} 6.09$ suggested a Dpg residue, supporting our predictions based on the Dpg biosynthetic proteins within the gene cluster. Correlations observed between several resonances in the region between $\delta \mathrm{H} 3.0-5.0$ are consistent with the presence of sugar moieties which we hypothesize to be incorporated by Chers 59 . Though exact resonances could not be assigned due to spectral overlap, resonances were identical to those observed in ramoplanin, which coupled with the presence of a putative mannosyltransferase within the BGC suggest D-mannoses are incorporated.

The N-acyl lipid was first assigned by 1D and 2D NMR. The 1D ${ }^{1} \mathrm{H}$ NMR displays a strong doublet at $\mathrm{OH} 0.65$ indicating a terminally branched lipid. Unlike the diagnostic spectra for the $Z, E$ unsaturated lipids of ramoplanin and enduracidin, the ${ }^{1} \mathrm{H}-\mathrm{NMR}$ of chersinamycin showed a lack of vinylic protons, and 2D spectra lacked correlations spanning the aliphatic-to-olefinic region, supporting our hypothesis of a saturated lipid based on the lack of ACADs in the gene cluster. To confirm saturation, chersinamycin was additionally subjected to catalytic hydrogenation. While hydrogenation of ramoplanin reduces both olefins resulting in a mass increase of $4 \mathrm{Da}$, no change was observed for chersinamycin after 24 hours under hydrogenation conditions.

After defining the amino acid, sugar, and lipid components of chersinamycin, the peptide connectivity hypothesized from in silico analysis of the chersinamycin NRPS domains was further examined through analysis of the NOESY spectrum. NOEs between adjacent amide protons and between amide protons and adjacent alpha/beta protons allowed for connectivity to be determined (Figure S19). Strong NOE correlations between residues 2 and 17 supported macrolactonization between these residues as had been predicted through bioinformatics. To further validate connectivity, we turned to MS/MS. Fragmentation focused on the molecular ion $[\mathrm{M}+2 \mathrm{H}]^{2+}(1287.05)$ resulted in two highly abundant doubly charged product ions of 1206.013 and 1124.986 , each consistent with a loss of a mannose residue from the core peptide. Unfortunately, the high fragmentation energy required to fragment the peptide resulted in many ions that were not diagnostic, a common occurrence with cyclic and glycosylated peptides. MS/MS of acyclic chersinamycin focused on the molecular ion $[\mathrm{M}+2 \mathrm{H}]^{2+}(1296.04)$ resulted in a more simplified spectrum (Figures S11, S12). Assignment of a number of $b$ - and y-ions validated that hydrolysis occurred between residues 2 and 17, and confirmed the connectivity shown in Figure 5.

Advanced Marfey's analysis was employed to confirm the absolute configuration of each amino acid. Following complete hydrolysis and derivatization with Marfey's reagent (FDAA), the hydrolysate of chersinamycin was analyzed by LC-MS and peaks were compared to authentic standards of FDAA-amino acids (Figure S13). It was determined that alanine and both ornithines are D-amino acids and valine, phenylalanine, and chlorohydroxyphenylglycine are L-amino acids. We observed a 1:1 ratio of D-Hpg:L-Hpg. Our chromatography method was able to unambiguously distinguish D/L-Thr from D/L-allo-Thr, allowing us to assign all threonines in chersinamycin as D-allo- and L-allo-Thr. The positions of 
bioRxiv preprint doi: https://doi.org/10.1101/2020.05.22.111625; this version posted May 25, 2020. The copyright holder for this preprint (which was not certified by peer review) is the author/funder, who has granted bioRxiv a license to display the preprint in perpetuity. It is made available under aCC-BY-NC-ND 4.0 International license.

D/L-amino acids in which both stereoisomers are present were assigned based on our analysis of the NRPS C/E domains. Unfortunately, asparagine and dihydroxyphenylglycine could not be identified in our FDAA-hydrolysate. As such, we were unable to confirm absolute configuration of these residues and assigned stereochemistry is based on the presence or absence of $\mathrm{C} / \mathrm{E}$ domains.

Cumulatively, our bioinformatics analyses paired with analytical structure elucidation assigns our $2574 \mathrm{Da}$ peptide from M. chersina as a 17-amino acid cyclic lipoglycodepsipeptide. The presence and location of D- and L-amino acids suggests chersinamycin's 3D structure to be very similar to ramoplanin and enduracidin. Unique from ramoplanin and enduracidin, chersinamycin exhibits a saturated $\mathrm{N}$-acyl lipid and a noncanonical Dpg residue within the peptide sequence. The observation of glycosylation is an advantageous structural feature for solubility, stability, and possible drug development. With the structure elucidated we next aimed to unambiguously confirm the BGC and establish antimicrobial activity.

Validation of the chersinamycin BGC using CRISPR-Cas9 gene editing. To confirm that the $M$. chersina BGC identified by genome mining was responsible for chersinamycin production, we performed an LC-MS screen of the mutant strain $M$. chersina $\triangle \mathrm{PKS7}$. This strain was constructed in an elegant investigation of the biosynthetic genes responsible for production of the anthraquinone scaffold in dynemicin biosynthesis ${ }^{66}$ and generously gifted to us by the Townsend Lab. It contains a 5.297 kilobase CRISPR-Cas9-mediated knockout of five genes encoding the putative biosynthesis enzymes for Dpg (Chers 29-33, Figure 6A,B). We observed that deletion of these biosynthetic genes resulted in the inability of $M$. chersina to produce chersinamycin. We rescued the knockout phenotype by the addition of $1 \mathrm{mM}$ Dpg to the production medium (Figure 6C). These studies establish the identity of the chersinamycin BGC and, importantly, demonstrated feasibility of genetic manipulation of this cluster.

Assessment of antimicrobial activity of chersinamycin. Chersinamycin was examined for its ability to inhibit bacterial growth by broth microdilution assays against Gram-positive strains B. subtilis ATCC 6051, S. aureus ATCC 25923, and E. faecalis ATCC 29212 and Gram-negative strain E. coli ATCC 25922. As our SAR-based search criteria biased our genome mining toward an active compound, we expected antimicrobial activity and mode of action to be consistent with what has been established for this family of antibiotics. Chersinamycin was found to be ineffective against E. coli but have potent antimicrobial activity against the Gram-positive strains (Table 1). Due to its structural similarities to ramoplanin, we expect activity against important clinically relevant pathogens such as $C$. difficile as well. As such, chersinamycin provides an additional potent ramoplanin family antibiotic for investigation into its antimicrobial potency and pharmacokinetic properties.

\section{CONCLUSIONS}

The emergence of resistance to nearly all our first line antibiotics has put enormous pressure on the development of new therapeutics. Ramoplanin is a potent antibiotic that is bactericidal against a number of clinically 
bioRxiv preprint doi: https://doi.org/10.1101/2020.05.22.111625; this version posted May 25, 2020. The copyright holder for this preprint (which was not certified by peer review) is the author/funder, who has granted bioRxiv a license to display the preprint in perpetuity. It is made available under aCC-BY-NC-ND 4.0 International license.

relevant Gram-positive pathogens, but poor bioavailability and stability highlight a need for development of next generation analogs with better pharmacological properties. We have reported a targeted genome mining strategy able to rapidly and reliably identify ramoplanin family gene clusters using established SAR. This has resulted in the discovery of five previously unidentified ramoplanin family BGCs in five additional bacterial strains. Of the strains identified, four have been previously cultured and extracted for other biologically active natural products, highlighting the importance of precise screening and extraction methods in identifying new natural products, and the significance of genome mining in natural product discovery. Bioinformatic analyses of putative proteins within the gene clusters allowed for structural predictions of the encoded natural products. These analyses predict 17-residue lipoglycodepsipeptides (from M. chersina and A. orientalis strains) and lipodepsipeptides (from A. balhimycina and Streptomyces sp. TLI_053) with high sequence similarity to ramoplanin and enduracidin, providing further support of what our group and others had concluded through SAR as to the significance of certain structural features for this class of antibiotics. Bettering our understanding of SAR through such analyses will aid in more insightful design of new antibiotics with improved biological properties.

To validate one of the five identified biosynthetic gene clusters, we isolated the new antibiotic chersinamycin from fermentation of $M$. chersina. We evaluated its covalent structure, and we used a CRISPR-Cas9-generated mutant strain to validate that this gene cluster produces chersinamycin. Thorough bioinformatic analysis paired with classical structure determination approaches allowed for structure elucidation, thus expanding this important antibiotic class for the first time since the discovery of ramoplanin over three decades ago. Chersinamycin retains many of the structural features of ramoplanin, including the presence of two mannose sugars which have been demonstrated to contribute to ramoplanin's stability and improved solubility over its sister compound enduracidin. The peptide was determined to have a saturated $\mathrm{N}$-acyl lipid, contrasting the lipid structures of the other two characterized compounds within this family and consistent with the lack of dehydrogenases within the identified gene cluster. Interestingly, the gene cluster retains the oxidoreductase (Chers 44$)$ which has been hypothesized to play a role in lipid unsaturation. Therefore, further investigation is needed to understand the lipid biosynthetic pathway in this antibiotic class, greater understanding of which may aid in the development of biosynthetic analogs with new lipid architectures of decreased hemolytic activity. ${ }^{16}$

Finally, the isolation of a ramoplanin family compound from a genetically tractable strain provides exciting opportunities for investigation of the biosynthetic pathway and development of biosynthetic analogs. Independently from this study, a CRISPR-Cas9 strategy was developed to produce a series of gene-inactivation mutants throughout the genome of $M$. chersina, a strategy that is difficult to achieve in many strains of natural product-producing organisms. ${ }^{66}$ We have demonstrated that one such mutant strain, M. chersina $\triangle \mathrm{PKS7}$, contains a knockout of the Dpg biosynthesis genes within the chersinamycin BGC that abolishes chersinamycin production. Our ability to rescue production through supplementation of Dpg in the production medium demonstrates the feasibility of CRISPR-mediated manipulation of 
bioRxiv preprint doi: https://doi.org/10.1101/2020.05.22.111625; this version posted May 25, 2020. The copyright holder for this preprint (which was not certified by peer review) is the author/funder, who has granted bioRxiv a license to display the preprint in perpetuity. It is made available under aCC-BY-NC-ND 4.0 International license.

this biosynthetic pathway. This work therefore presents exciting opportunities for targeted gene inactivation to investigate enzymes within the chersinamycin biosynthetic pathway, as well as to produce biosynthetic analogs.

\section{MATERIALS AND METHODS}

General methods and materials. Bacterial cell culture media components were purchased from Affymetrix, Fisher Scientific, Millipore-Sigma, and BD Difco Laboratories. A sample of Pharmamedia was obtained from Archer Daniels Midland Company, and fish meal was purchased from Coyote Creek Organic Feed Mill and Farm. Ultra-high purity solvents were purchased from Millipore-Sigma and Fisher Scientific and used without further purification. All chemicals were purchased in their highest purity forms from Millipore-Sigma and used without further purification unless otherwise indicated. The 1D and 2D NMR spectra (COSY, TOCSY, NOESY) were collected on a Varian/Agilent DirectDrive2 spectrometer at $800 \mathrm{MHz}$. Preparative reverse-phase HPLC purifications were performed on a Waters Prep 150B system with a Phenomenex octadecyl silica $\left(C_{18}\right)$ column $(250 \mathrm{~mm} \times 21 \mathrm{~mm}, 10 \mu \mathrm{m}, 300 \AA)$ or Vydac $C_{18}$ column (250 x 10 mm, $5 \mu \mathrm{m}, 300 \AA$ A). Analytical HPLC was performed on a Varian Prostar system with a Phenomenex $\mathrm{C}_{18}$ column $(250 \times 4.6 \mathrm{~mm}, 5 \mu \mathrm{m}, 300 \AA$ ) $)$. Tandem MS/MS spectrometry was performed using a Fusion Lumos Orbitrap mass spectrometer. Matrix-assisted laser desorption time-of-flight mass spectrometry (MALDI-TOF) was performed using a Bruker Autoflex Speed LRF MALDI-TOF System. High-resolution mass spectra were collected on an Agilent 6224 LC/MS-TOF instrument.

Bioinformatics. The NCBI accession numbers for the ramoplanin and enduracidin biosynthetic gene loci are DD382878 and DQ403252, respectively. NRPS A, NRPS B, NRPS C, NRPS D, the terminal thioesterase subdomain from NRPS C, the FAAL, and the ACP were used as initial queries for protein blast searches against the NCBI database. Sequences with $>50 \%$ identity were collected and organisms that had four or more homologous proteins to the search queries were considered hits. Whole genome sequences for these organisms were obtained from NCBI GenBank and open reading frames within 40 ORFs on either side of NRPS B were analyzed. A total of 1069 translated sequences were subjected to an all vs. all blast and assembled into a sequence similarity network with an $E$ value limit of $10^{-5}$ and alignment score of 50 using EFI-Enzyme Similarity Tool. The network was visualized using Cytoscape (version 3.7.1, from the National Resource of Network Biology). From the initial network five genomes were selected as having enough clustered proteins for a full BGC and were assembled into a more targeted SSN using an E value limit of $10^{-5}$ and alignment scores of 25 and 50. Manual analysis was complemented with antiSMASH 4.0 using the following: FMIB01000002.1 (M. chersina strain DSM 44151, cluster 1), NZ_CP016174 (A. orientalis strain B-37, cluster 13) NZ_ASJB01000042 (A. orientalis strain DSM 40040), NZ_KB913037 (A. balhimycina FH 1894 strain DSM 44591, clusters 1, 28), NZ_LT629775 (Streptomyces sp. TLI_053, cluster 18).

Antibiotic production screening in M. chersina DSM 44151. To prepare the seed culture, a frozen aliquot of M. chersina vegetative stock (4 mL, See Supplemental Information) was thawed on ice, then used to inoculate a 500 
bioRxiv preprint doi: https://doi.org/10.1101/2020.05.22.111625; this version posted May 25, 2020. The copyright holder for this preprint (which was not certified by peer review) is the author/funder, who has granted bioRxiv a license to display the preprint in perpetuity. It is made available under aCC-BY-NC-ND 4.0 International license.

$\mathrm{mL}$ baffled flask containing $100 \mathrm{~mL}$ of medium 53 and was incubated at $28{ }^{\circ} \mathrm{C}$ for seven days with shaking at $250 \mathrm{rpm}$. For antibiotic production, seed culture $(4 \mathrm{~mL})$ was used to inoculate a $500 \mathrm{~mL}$ flask containing $100 \mathrm{~mL}$ of each of following media: dynemicin production medium H881 (10 $\mathrm{g} \mathrm{L}^{-1}$ starch; $5 \mathrm{~g} \mathrm{~L}^{-1}$ Pharmamedia; $1 \mathrm{~g} \mathrm{~L}^{-1} \mathrm{CaCO}_{3} ; 0.05 \mathrm{~g} \mathrm{~L}^{-1}$ $\mathrm{CuSO}_{4}$; and $\left.0.5 \mathrm{mg} \mathrm{L}^{-1} \mathrm{Nal}\right) ;{ }^{62} \mathrm{H} 881$ medium with chicken oil $\left(14 \mathrm{~mL} \mathrm{~L}^{-1}\right)$; H881 medium with glucose $\left(30 \mathrm{~g} \mathrm{~L}^{-1}\right)$; enduracidin growth medium (80 $\mathrm{g} \mathrm{L}^{-1}$ corn flour; $30 \mathrm{~g} \mathrm{~L}^{-1}$ corn gluten meal; $5 \mathrm{~mL} \mathrm{~L}^{-1}$ corn steep liquor; $3 \mathrm{~g} \mathrm{~L}^{-1}$ ammonium sulfate; $1 \mathrm{~g} \mathrm{~L}^{-1} \mathrm{NaCl} ; 10 \mathrm{mg} \mathrm{L}^{-1} \quad \mathrm{ZnCl}_{2} ; 10 \mathrm{~g} \mathrm{~L}^{-1}$ lactose; $10 \mathrm{~mL} \mathrm{~L}^{-1}$ potassium lactate; and $14 \mathrm{~mL} \mathrm{~L}^{-1}$ chicken oil), ${ }^{61}$ or ramoplanin production medium (50 g L-1 starch; $30 \mathrm{~g} \mathrm{~L}^{-1}$ glucose; $30 \mathrm{~g} \mathrm{~L}^{-1}$ soy flour; $10 \mathrm{~g} \mathrm{~L}^{-1} \mathrm{CaCO}_{3}$; $5 \mathrm{~g} \mathrm{~L}^{-1}$ leucine). ${ }^{39}$ The chicken oil supplement was prepared by defatting 1 whole roasting chicken (Harris Teeter, Inc.), rendering the isolated fat and skin at $350^{\circ} \mathrm{C}$ for $15 \mathrm{~min}$, cooling the mixture to rt, and clarifying the oil by centrifugation (15 min, $4,000 \mathrm{rpm}, 4^{\circ} \mathrm{C}$ ). The oil was stored in the dark at $4{ }^{\circ} \mathrm{C}$ for up to 2 days prior to use.

Production cultures of $M$. chersina were grown at $28{ }^{\circ} \mathrm{C}, 250 \mathrm{rpm}$ for $12-21$ days. Antibiotic production was monitored by MALDI-TOF MS screening. For screening, cell culture aliquots $(6 \mathrm{~mL})$ were pelleted by centrifugation at $5000 \mathrm{rpm}$ for 15 minutes at $4{ }^{\circ} \mathrm{C}$. The supernatant was separated from the cell pellet by decantation and the supernatant fraction was extracted with ethyl acetate. The organic fraction was separated, dried with sodium sulfate, and freed of solvent under vacuum. Both the aqueous and organic fractions were analyzed by MALDI-TOF MS for production of secondary metabolites in the 2000-3000 Da MW range. Similarly, the production culture aliquot cell pellet was resuspended in acidic aqueous $\mathrm{MeOH} / \mathrm{H}_{2} \mathrm{O}(66: 33 \mathrm{v} / \mathrm{v} ; \mathrm{pH} 3,6 \mathrm{~mL})$, stirred at it for $3 \mathrm{~h}$ to affect cell lysis, centrifuged (5000 rpm, $10 \mathrm{~min}, 4^{\circ} \mathrm{C}$ ), and the supernatant was decanted and extracted with EtOAc as above. Both the aqueous and organic fractions were analyzed by MALDI-TOF MS. The antibiotic peptide was observed in the aqueous fraction of the extracted cell pellet, which was used for further analyses.

Large scale production, isolation, and purification of chersinamycin from M. chersina DSM 44151. For large scale production of chersinamycin from M. chersina, $20 \mathrm{~mL}$ of seed culture was used to inoculate $2 \mathrm{~L}$ baffled flasks containing $500 \mathrm{~mL} \mathrm{H881} \mathrm{media} \mathrm{and} \mathrm{grown} \mathrm{at} 28^{\circ} \mathrm{C}, 250 \mathrm{rpm}$ for 12 days. Cells were pelleted by centrifugation, resuspended in acidic aqueous $\mathrm{MeOH}(300 \mathrm{~mL})$, stirred at $\mathrm{rt}$ for $3 \mathrm{~h}$ at $\mathrm{rt}$, then centrifuged to remove cellular debris as described above. The supernatant was extracted with EtOAc $(3 \times 300 \mathrm{~mL})$ to remove organic-soluble metabolites. The aqueous layer was freeze-dried, dissolved in an $\mathrm{H}_{2} \mathrm{O} / \mathrm{MeCN}$ mixture, and subjected to RP-HPLC using a Jupiter C18, $250 \times 21.2 \mathrm{~mm}$ column with a linear gradient of $20-50 \%$ B over 30 minutes, where solvent $A$ was $0.1 \%$ TFA in $\mathrm{H}_{2} \mathrm{O}$ and B was $0.06 \%$ TFA in MeCN. A second HPLC purification was performed using a Vydac C18 $250 \times 10 \mathrm{~mm}$ column with the same solvent system as above and a linear gradient of $20-35 \%$ B over 50 minutes to yield pure chersinamycin in 1-3 $\mathrm{mg} \mathrm{L}^{-1}$ quantities from the starting cell culture.

Advanced Marfey's analysis of chersinamycin and ramoplanin. To facilitate the hydrolysis of chersinamycin and ramoplanin for advanced Marfey's analysis, to a thick walled glass vial $(10 \mathrm{~mL})$ containing either lyophilized chersinamycin $(0.8 \mathrm{mg}, 311 \mathrm{pmol})$ or ramoplanin $(1 \mathrm{mg}, 392 \mathrm{pmol})$ was added freshly prepared $6 \mathrm{M} \mathrm{HCl}$ 
bioRxiv preprint doi: https://doi.org/10.1101/2020.05.22.111625; this version posted May 25, 2020. The copyright holder for this preprint (which

was not certified by peer review) is the author/funder, who has granted bioRxiv a license to display the preprint in perpetuity. It is made available under aCC-BY-NC-ND 4.0 International license.

$(200 \mu \mathrm{L})$. After flushing the vial with $\mathrm{Ar}$ for $20 \mathrm{~min}$, the vial was sealed and heated at $110^{\circ} \mathrm{C}$ for $18 \mathrm{hrs}$. The reaction mixtures were cooled, evaporated under a stream of $\mathrm{N}_{2}$, dissolved in $\mathrm{TEA} / \mathrm{H}_{2} \mathrm{O}(25: 75, \mathrm{v} / \mathrm{v}, 100 \mu \mathrm{L})$, transferred to a 5 $\mathrm{mL}$ round bottom flask, and evaporated under reduced pressure to dryness. The latter sequence was repeated 2 additional times. The resulting residue was dissolved in $\mathrm{H}_{2} \mathrm{O}(75 \mu \mathrm{L})$, sodium bicarbonate $(1 \mathrm{M}, 40 \mu \mathrm{L})$ and TEA $(25 \mu \mathrm{L})$ were added, and the mixture was transferred to a $1.7 \mathrm{~mL}$ amber Eppendorf tube. Marfey's reagent (1.4 $\mathrm{mg})$ in acetone $(100 \mu \mathrm{L})$ was added and the mixture was heated for $1 \mathrm{~h}$ at $40^{\circ} \mathrm{C}$ with periodic vortexing. After cooling to rt, $\mathrm{HCl}(2 \mathrm{M}, 10$ $\mu \mathrm{L}$ ) was added and the reaction mixture was dried overnight in a vacuum desiccator. For HPLC analysis, dried reaction mixtures were dissolved in DMSO $(0.5 \mathrm{~mL})$. A $50 \mu \mathrm{L}$ aliquot was used to make a 1:1 dilution in water and filtered through a $0.2 \mu \mathrm{m}$ syringe filter. RP-HPLC-MS analysis was performed with at Kintex $2.6 \mu \mathrm{m}$ EVO-C18, $100 \times 3 \mathrm{~mm}$ column with a gradient of $5-50 \%$ B over 40 minutes, where solvent $A$ was 100:3:0.3 $\mathrm{H}_{2} \mathrm{O} / \mathrm{MeOH} / \mathrm{TFA}$ and solvent $\mathrm{B}$ was 100:3:0.3 MeCN/H $2 \mathrm{O} / T F A$. ESI-MS for FDAA-amino acids was performed in negative ion mode.

Structural determination by 1D and 2D NMR and ESI-MS/MS. Pure chersinamycin ( $3 \mathrm{mg}, 2.6 \mathrm{mM})$ was dissolved in 4:1 $\mathrm{H}_{2} \mathrm{O} / \mathrm{DMSO}-\mathrm{d}_{6}(\mathrm{v} / \mathrm{v})$ or 4:1 $\mathrm{D}_{2} \mathrm{O} / \mathrm{DMSO}-\mathrm{d}_{6}$ at $\mathrm{pH}$ 4.56. Homonuclear experiments were acquired with a spectral width of $11 \mathrm{ppm}$. Mixing times of 80 and $500 \mathrm{~ms}$ were used for TOCSY and NOESY spectra, respectively. Solvent suppression was employed at $2.50 \mathrm{ppm}(\mathrm{DMSO})$ and $4.54 \mathrm{ppm}\left(\mathrm{H}_{2} \mathrm{O}\right)$ and spectra were referenced to DMSO. For ESI-MS/MS analysis, pure cyclic and acyclic peptides dissolved in 4:1 $\mathrm{H}_{2} \mathrm{O} / \mathrm{MeCN}(\mathrm{v} / \mathrm{v})$ were diluted 1:20 with 1:1 $\mathrm{H}_{2} \mathrm{O} / \mathrm{MeCN}(\mathrm{v} / \mathrm{v})$ with $0.2 \%$ formic acid and infused into a Fusion Lumos Orbitrap mass spectrometer at $2.5 \mu \mathrm{L} \mathrm{min}^{-1}$. Data was collected at $120 \mathrm{~K}$ for full MS scans and $30 \mathrm{~K}$ for MS/MS scans. The intact peptide was subjected to MS/MS higher-energy C-trap dissociation (HCD) fragmentation in both the $[\mathrm{M}+2 \mathrm{H}]^{2+}$ and $[\mathrm{M}+3 \mathrm{H}]^{3+}$ charge states.

\section{Genetic and biochemical confirmation of antibiotic production by the predicted chersinamycin BGC. A} frozen aliquot $(100 \mu \mathrm{L})$ of mycelia from the M. chersina Dpg deletion mutant strain $\Delta \mathrm{PKS} 7^{66}$ was thawed on ice, plated onto medium 53 agar, and incubated at $28{ }^{\circ} \mathrm{C}$ for five days. Sterile liquid medium 53 was added to the plate $(2 \mathrm{~mL})$ and the plate was scraped to resuspend the cells. This suspension was added to a sterile culture flask (125 $\mathrm{mL}$ ) containing medium $53(50 \mathrm{~mL})$, and the mixture was incubated for seven days at $28^{\circ} \mathrm{C}$ with shaking at $250 \mathrm{rpm}$. An aliquot of this seed culture $(2 \mathrm{~mL})$ was used to inoculate $\mathrm{H} 881$ media $(50 \mathrm{~mL})$ in a $250 \mathrm{~mL}$ sterile culture flask, which was incubated at $28{ }^{\circ} \mathrm{C}$ for 12 days with shaking $(250 \mathrm{rpm})$. Following centrifugation, the production cell pellet was extracted with acidic aqueous $\mathrm{MeOH} / \mathrm{H}_{2} \mathrm{O}(66: 33 \mathrm{v} / \mathrm{v} ; \mathrm{pH} \mathrm{3}, 50 \mathrm{~mL})$ for 3 hours at rt. Cell debris was removed by centrifugation and the supernatant was subjected to HPLC-MS analysis for validation of the absence of detectible chersinamycin. To restore chersinamycin production through chemical complementation, $M$. chersina strain $\triangle \mathrm{PKS} 7$ was fermented in H881 production medium that was supplemented with racemic $(R, S)-3,5-\mathrm{Dpg}(1 \mathrm{mM}$, Millipore-Sigma). Production cultures were incubated identically as above, the cell pellets were isolated by centrifugation, and then extracted and analyzed by HPLC-MS. 
bioRxiv preprint doi: https://doi.org/10.1101/2020.05.22.111625; this version posted May 25, 2020. The copyright holder for this preprint (which was not certified by peer review) is the author/funder, who has granted bioRxiv a license to display the preprint in perpetuity. It is made available under aCC-BY-NC-ND 4.0 International license.

Minimal inhibitory concentration assays. Antibacterial activity of chersinamycin and positive controls (vancomycin, ampicillin, and ramoplanin A2,) were determined by the broth microdilution assay method. Briefly, bacterial strains were grown in cation-adjusted Mueller-Hinton broth. A microtiter plate was prepared by coating wells in $0.2 \% \mathrm{BSA}$, and antimicrobial peptides were added with 2-fold dilution steps ranging from $64-0.125 \mu \mathrm{gL}^{-1}$. Bacteria was added to a final concentration of $10^{5}$ colony forming units and final volume of $100 \mu \mathrm{L}$. Plates were incubated at 37 ${ }^{\circ} \mathrm{C}$ for 24 hours, and the MIC was read as the lowest peptide concentration for which no bacterial growth was visualized. Reported values are the average of two replicates.

\section{ASSOCIATED CONTENT}

Supporting Information. The Supporting Information is available and contains:

General methods of bacterial culture, antibiotic screening in A. orientalis and A. balhimycina, and semisynthetic derivatizations of chersinamycin.

Detailed annotations of the bacterial strains and biosynthetic gene clusters analyzed in this study, MS and NMR data for chersinamycin

\section{Accession Codes}

Ramoplanin biosynthetic gene cluster, Accession DD382878; Enduracidin biosynthetic gene cluster, DQ403252; Micromonospora chersina DSM 44151, Accession FMIB01000002.1; Amycolatopsis orientalis strain B-37, Accession NZ_CP016174; Amycolatopsis orientalis DSM 40040 = KCTC 4912, Accession NZ_ASJB01000042; Amycolatopsis balhimycina FH 1894 DSM 44591, Accession NZ_KB913037; Streptomyces sp. TLI_053, Accession NZ_LT629775; Micromonospora sp. MH33, Accession NZ_MUYZ00000000.1; Amycolatopsis thailandensis strain JCM 16380, Accession NZ_NMQT00000000.1; Actinomadura madurae LIID-AJ290, Accession NZ_AW0002000001.1; Actinomadura madurae strain DSM 43067, Accession NZ_FOVH00000000.1; Streptomyces vietnamensis strain GIM4.0001, Accession NZ_CP010407.1; Streptomyces sp. GP55, Accession NZ_PJMT01000001.1; Streptomyces cinnamoneus strain ATCC 21532, Accession NZ_NHZO00000000.1; Streptomyces cinnamoneus strain DSM 41675, Accession NZ_PKFQ01000001.1

\section{AUTHOR INFORMATION}

\section{Corresponding Author}

*Department of Chemistry, Duke University, B120 Levine Science Research Center, 450 Research Dr., Durham, NC 27708. E-mail: dewey.mccafferty@duke.edu. Phone: (919) 660-1516. Fax: (919) 660-1605.

\section{ORCID}

Kelsey Morgan: 0000-0003-2530-015X

\section{Notes}

The authors declare no competing financial interests. 
bioRxiv preprint doi: https://doi.org/10.1101/2020.05.22.111625; this version posted May 25, 2020. The copyright holder for this preprint (which

was not certified by peer review) is the author/funder, who has granted bioRxiv a license to display the preprint in perpetuity. It is made available under aCC-BY-NC-ND 4.0 International license.

\section{ACKNOWLEDGMENTS}

The authors gratefully acknowledge Drs. Craig Townsend and Douglas Cohen for the generous gift of Micromonospora chersina strain $\triangle \mathrm{PKS7}$, Dr. Peter Silinski for mass spectrometry assistance, Drs. Anthony Ribeiro, Benjamin Bobay, and the Duke NMR Facility for NMR assistance, and the Duke University School of Medicine for the use of Proteomics and Metabolomics Shared Resource, which provided MS/MS sequencing of chersinamycin.

\section{ABBREVIATIONS}

PG: peptidoglycan; BGC: biosynthetic gene cluster; NRPS: nonribosomal peptide synthetase; ORF: open reading frame; FAAL: fatty acyl-AMP ligase; ACP: acyl carrier protein; ACAD: acyl-CoA dehydrogenase; SSN: sequence similarity network;

Hpg: 4-hydroxyphenylglycine; Dpg: 3,5-dihydroxyphenylglycine; Orn: ornithine; End: enduracididine; ClHpg: 3chlorohydroxyphenylglycine; diClHpg: 3,5-dichlorohydroxyphenylglycine

\section{REFERENCES}

(1) Clardy, J., Fischbach, M. A., and Walsh, C. T. (2006) New antibiotics from bacterial natural products. Nat. Biotechnol. 24, 1541-1550.

(2) Nicolaou, K. C., Boddy, C. N. C., Bräse, S., and Winssinger, N. (1999) Chemistry, biology, and medicine of the glycopeptide antibiotics. Angew. Chemie Int. Ed. 38, 2096-2152.

(3) Yim, G., Wang, W., Thaker, M. N., Tan, S., and Wright, G. D. (2016) How to make a glycopeptide: A synthetic biology approach to expand antibiotic chemical diversity. ACS Infect. Dis. 2, 642-650.

(4) Cavalleri, B., Pagani, H., Volpe, G., Selva, E., and Parenti, F. (1984) A-16686, a new antibiotic from Actinoplanes. I. Fermentation, isolation and preliminary physico-chemical characteristics. J. Antibiot. (Tokyo). XXXVII, 309-317.

(5) Parenti, F., Ciabatti, R., Cavalleri, B., and Kettenring, J. (1990) Ramoplanin: a review of its discovery and its chemistry. Drugs Exp. Clin. Res. 16, 451-455.

(6) Cavalleri, B., and Selva, E. (1984) Antibiotic A/1 6686 factor A2, the process for the preparation thereof, and the co-produced antibiotic A/1 6686 factors A1 and A3. . United States Patent Office.

(7) Gastaldo, L., Ciabatti, R., Assi, F., Restelli, E., Kettenring, J. K., Zerilli, L. F., Romanò, G., Denaro, M., and Cavalleri, B. (1992) Isolation, structure determination and biological activity of A-16686 factors $A^{\prime} 1, A^{\prime} 2$ and $A^{\prime} 3$ glycolipodepsipeptide antibiotics. J. Ind. Microbiol. 11, 13-18.

(8) Castiglione, F., Marazzi, A., Meli, M., and Colombo, G. (2005) Structure elucidation and 3D solution conformation of the antibiotic enduracidin determined by NMR spectroscopy and molecular dynamics. Magn. Reson. Chem. 43, 603-610. 
bioRxiv preprint doi: https://doi.org/10.1101/2020.05.22.111625; this version posted May 25, 2020. The copyright holder for this preprint (which was not certified by peer review) is the author/funder, who has granted bioRxiv a license to display the preprint in perpetuity. It is made available under aCC-BY-NC-ND 4.0 International license.

(9) McCafferty, D. G., Cudic, P., Frankel, B. A., Barkallah, S., Kruger, R. G., and Li, W. (2002) Chemistry and biology of the ramoplanin family of peptide antibiotics. Biopolymers 66, 261-284.

(10) Fang, X., Tiyanont, K., Zhang, Y., Wanner, J., Boger, D., and Walker, S. (2006) The mechanism of action of ramoplanin and enduracidin. Mol. Biosyst. 2, 69-76.

(11) Cheng, M., Huang, J. X., Ramu, S., Butler, M. S., and Cooper, M. A. (2014) Ramoplanin at bactericidal concentrations induces bacterial membrane depolarization in Staphylococcus aureus. Antimicrob. Agents Chemother. 58, 6819-27.

(12) Mobarakai, N., Quale, J. M., and Landman, D. (1994) Bactericidal activities of peptide antibiotics against multidrug-resistant Enterococcus faecium. Antimicrob. Agents Chemother. 38, 385-7.

(13) Montecalvo, M. A. (2003) Ramoplanin: a novel antimicrobial agent with the potential to prevent vancomycinresistant enterococcal infection in high-risk patients. J. Antimicrob. Chemother. 51 Supp/ 3, iii31-5.

(14) Pallanza, R., Berti, M., Scotti, R., Randisi, E., and Arioli, V. (1984) A-16686, a new antibiotic from Actinoplanes: II. Biological properties. J. Antibiot. (Tokyo). 37, 318-324.

(15) Walker, S., Chen, L., Hu, Y., Rew, Y., Shin, D., and Boger, D. L. (2005) Chemistry and biology of ramoplanin: A lipoglycodepsipeptide with potent antibiotic activity. Chem. Rev. 105, 449-475.

(16) Ciabatti, R., Maffioli, S. I., Panzone, G., Canavesi, A., Michelucci, E., Tiseni, P. S., Marzorati, E., Checchia, A., Giannone, M., Jabes, D., Romanò, G., Brunati, C., Candiani, G., and Castiglione, F. (2007) Synthesis and preliminary biological characterization of new semisynthetic derivatives of ramoplanin. J. Med. Chem. 50, 30773085.

(17) Goto, S., Kuwahara, S., Okubo, N., and Zenyoji, H. (1968) In vitro and in vivo evaluation of enduracidin, a new peptide antibiotic substance. J. Antibiot. (Tokyo). 21, 119-125.

(18) Tsuchiya, K., Kondo, M., Oishi, T., and Yamazaki, I. (1968) Enduracidin, a new antibiotic. 3. In vitro and in vivo antimicrobial activity. J. Antibiot. (Tokyo). 21, 147-53.

(19) Peláez, T., Alcalá, L., Alonso, R., Martín-López, A., García-Arias, V., Marín, M., and Bouza, E. (2005) In vitro activity of ramoplanin against Clostridium difficile, including strains with reduced susceptibility to vancomycin or with resistance to metronidazole. Antimicrob. Agents Chemother. 49, 1157-1159.

(20) Petrosillo, N., Granata, G., and Cataldo, M. A. (2018) Novel antimicrobials for the treatment of Clostridium difficile infection. Front. Med. 5, 96.

(21) Basśres, E., Endres, B. T., Dotson, K. M., Jahangir Alam, M., and Garey, K. W. (2017) Novel antibiotics in development to treat Clostridium difficile infection. Curr. Opin. Gastroenterol. 33, 1-7. 
bioRxiv preprint doi: https://doi.org/10.1101/2020.05.22.111625; this version posted May 25, 2020. The copyright holder for this preprint (which was not certified by peer review) is the author/funder, who has granted bioRxiv a license to display the preprint in perpetuity. It is made available under ACC-BY-NC-ND 4.0 International license.

(22) Kraus, C. N., Lyerly, M. W., and Carman, R. J. (2015) Ambush of Clostridium difficile spores by ramoplanin: activity in an in vitro model. Antimicrob. Agents Chemother. 59, 2525-2530.

(23) de la Cruz, M., González, I., Parish, C. A., Onishi, R., Tormo, J. R., Martín, J., Peláez, F., Zink, D., El Aouad, N., Reyes, F., Genilloud, O., and Vicente, F. (2017) Production of ramoplanin and ramoplanin analogs by Actinomycetes. Front. Microbiol. 8, 343.

(24) Li, X.-G., Tang, X.-M., Xiao, J., Ma, G.-H., Xu, L., Xie, S.-J., Xu, M.-J., Xiao, X., and Xu, J. (2013) Harnessing the potential of halogenated natural product biosynthesis by mangrove-derived Actinomycetes. Mar. Drugs 11, 3875-3890.

(25) Ziemert, N., Alanjary, M., and Weber, T. (2016) The evolution of genome mining in microbes - a review. Nat. Prod. Rep. 33, 988-1005.

(26) Cudic, P., Kranz, J. K., Behenna, D. C., Kruger, R. G., Tadesse, H., Wand, A. J., Veklich, Y. I., Weisel, J. W., and Mccafferty, D. G. (2002) Complexation of peptidoglycan intermediates by the lipoglycodepsipeptide antibiotic ramoplanin: Minimal structural requirements for intermolecular complexation and fibril formation. Proc. Natl. Acad. Sci. U. S. A. 99, 7384-7389.

(27) Somner, E. A., and Reynolds, P. E. (1990) Inhibition of peptidoglycan biosynthesis by ramoplanin. Antimicrob. Agents Chemother. 34, 413-419.

(28) Farnet, C. M., Zazopoulos, E., and Staffa, A. (2001) Gene cluster for ramoplanin biosynthesis. European Patent Office.

(29) Yin, X., and Zabriskie, T. M. (2006) The enduracidin biosynthetic gene cluster from Streptomyces fungicidicus. Microbiology 152, 2969-2983.

(30) Fang, X., Nam, J., Shin, D., Rew, Y., Boger, D. L., and Walker, S. (2009) Functional and biochemical analysis of a key series of ramoplanin analogues. Bioorg. Med. Chem. Lett. 19, 6189-6191.

(31) Hamburger, J. B., Hoertz, A. J., Lee, A., Senturia, R. J., Mccafferty, D. G., and Loll, P. J. (2009) A crystal structure of a dimer of the antibiotic ramoplanin illustrates membrane positioning and a potential Lipid II docking interface. Proc. Natl. Acad. Sci. U. S. A. 106, 13759-13764.

(32) Nam, J., Shin, D., Rew, Y., and Boger, D. L. (2007) Alanine scan of [L-Dap2]ramoplanin A2 aglycon: Assessment of the importance of each residue. J. Am. Chem. Soc. 129, 8747-8755.

(33) Jiang, W., Wanner, J., Lee, R. J., Bounaud, P.-Y., and Boger, D. L. (2003) Total synthesis of the ramoplanin A2 and ramoplanose aglycon. J. Am. Chem. Soc. 125, 1877-1887.

(34) Rew, Y., Shin, D., Hwang, I., and Boger, D. L. (2004) Total synthesis and examination of three key 
bioRxiv preprint doi: https://doi.org/10.1101/2020.05.22.111625; this version posted May 25, 2020. The copyright holder for this preprint (which was not certified by peer review) is the author/funder, who has granted bioRxiv a license to display the preprint in perpetuity. It is made available under aCC-BY-NC-ND 4.0 International license.

analogues of ramoplanin: A lipoglycodepsipeptide with potent antibiotic activity. J. Am. Chem. Soc. 126, 10411043.

(35) Chen, L., Yuan, Y., Helm, J. S., Hu, Y., Rew, Y., Shin, D., Boger, D. L., and Walker, S. (2004) Dissecting ramoplanin: Mechanistic analysis of synthetic ramoplanin analogues as a guide to the design of improved antibiotics. J. Am. Chem. Soc. 126, 7462-7463.

(36) Lo, M.-C., Helm, J. S., Sarngadharan, G., Pelczer, I., Walker, S., Mei-Chu Lo, Jeremiah S. Helm, Gopal Sarngadharan, Pelczer, I., and Walker, S. (2001) A new structure for the substrate-binding antibiotic ramoplanin. J. Am. Chem. Soc. 123, 8640-8641.

(37) Hu, Y., Helm, J. S., Chen, L., Ye, X.-Y., and Walker, S. (2003) Ramoplanin inhibits bacterial transglycosylases by binding as a dimer to Lipid II. J. Am. Chem. Soc. 125, 8736-8737.

(38) Cudic, P., Behenna, D. C., Kranz, J. K., Kruger, R. G., Wand, A. J., Veklich, Y. I., Weisel, J. W., and McCafferty, D. G. (2002) Functional analysis of the lipoglycodepsipeptide antibiotic ramoplanin. Chem. Biol. 9, 897-906.

(39) Chen, J.-S., Wang, Y.-X., Shao, L., Pan, H.-X., Li, J.-A., Lin, H.-M., Dong, X.-J., and Chen, D.-J. (2013) Functional identification of the gene encoding the enzyme involved in mannosylation in ramoplanin biosynthesis in Actinoplanes sp. Biotechnol. Lett. 35, 1501-1508.

(40) Struck, A.-W., Wu, M.-C., Nunns, L., Styles, M. Q., Micklefield, J., and Law, B. J. C. (2015) Engineered biosynthesis of enduracidin lipoglycopeptide antibiotics using the ramoplanin mannosyltransferase Ram29. Microbiology 161, 1338-1347.

(41) Kurz, M., and Guba, W. (1996) 3D structure of ramoplanin: A potent inhibitor of bacterial cell wall synthesis. Biochemistry 35, 12570-12575.

(42) Maplestone, R. A., Cox, J. P. L., and Williams, D. H. (1993) Retention of native-like structure in an acyclic counterpart of a $\beta$-sheet antibiotic. FEBS Lett. 326, 95-100.

(43) Yin, X., Chen, Y., Zhang, L., Wang, Y., and Zabriskie, T. M. (2010) Enduracidin analogues with altered halogenation patterns produced by genetically engineered strains of Streptomyces fungicidicus. J. Nat. Prod. 73, 583-589.

(44) Pan, H. X., Chen, Z. Z., Shao, L., Li, J. A., Chen, J. S., Zhu, C. B., Tang, G. L., and Chen, D. J. (2013) Production of ramoplanin analogues by genetic engineering of Actinoplanes sp. Biotechnol. Lett. 35, 1685-1692. (45) Shin, D., Rew, Y., and Boger, D. L. (2004) Total synthesis and structure of the ramoplanin A1 and A3 aglycons: Two minor components of the ramoplanin complex. Proc. Natl. Acad. Sci. U. S. A. 101, 11977-11979. 
bioRxiv preprint doi: https://doi.org/10.1101/2020.05.22.111625; this version posted May 25, 2020. The copyright holder for this preprint (which was not certified by peer review) is the author/funder, who has granted bioRxiv a license to display the preprint in perpetuity. It is made

(46) Skelton, N. J., Harding, M. M., Mortishire-Smith, R. J., Rahman, S. K., Williams, D. H., Ranee, M. J., and

Ruddock, J. C. (1991) Structure elucidation and solution conformation of the glycopeptide antibiotic ramoplanose (UK-71,903): A cyclic depsipeptide containing an antiparallel $\beta$-sheet and a $\beta$-bulge. J. Am. Chem. Soc. 113, 7522-7530.

(47) Lo, M. C., Men, H., Branstrom, A., Helm, J., Yao, N., Goldman, R., and Walker, S. (2000) A new mechanism of action proposed for ramoplanin. J. Am. Chem. Soc. 122, 3540-3541.

(48) Ciabatti, R., and Cavalleri, B. (1988) Novel hydrogenated derivatives of antibiotic A/16686. United States Patent Office.

(49) Han, J., Chen, J., Shao, L., Zhang, J., Dong, X., Liu, P., and Chen, D. (2016) Production of the ramoplanin activity analogue by double gene inactivation. PLoS One 11, e0154121.

(50) Chen, J.-S., Su, M., Shao, L., Wang, Y.-X., Lin, H.-M., and Chen, D.-J. (2016) Investigation of halogenation during the biosynthesis of ramoplanin in Actinoplanes sp. ATCC33076. Appl. Microbiol. Biotechnol. 100, 289298.

(51) Gerlt, J. A., Bouvier, J. T., Davidson, D. B., Imker, H. J., Sadkhin, B., Slater, D. R., and Whalen, K. L. (2015) Enzyme function initiative-enzyme similarity tool (EFI-EST): A web tool for generating protein sequence similarity networks. Biochim. Biophys. Acta - Proteins Proteomics 1854, 1019-1037.

(52) McCormick, M. H., McGuire, J. M., Pittenger, G. E., Pittenger, R. C., and Stark, W. M. (1955) Vancomycin, a new antibiotic. I. Chemical and biologic properties. Antibiot. Annu. 3, 606-611.

(53) Wink, J. M., Kroppenstedt, R. M., Ganguli, B. N., Nadkarni, S. R., Schumann, P., Seibert, G., and Stackebrandt, E. (2003) Three new antibiotic producing species of the genus Amycolatopsis, Amycolatopsis balhimycina sp. nov., A. tolypomycina sp. nov., A. vancoresmycina sp. nov., and description of Amycolatopsis keratiniphila subsp. keratiniphila subsp. nov. and A. keratiniphila subsp. nogabecina subsp. nov. Syst. Appl. Microbiol. 26, 38-46.

(54) Konishi, M., Ohkuma, H., Matsumoto, K., Saitoh, K., Miyaki, T., Oki, T., and Kawaguchi, H. (1991) Dynemicins, new antibiotics with the 1,5-diyn-3-ene and anthraquinone subunit. I. Productin, isolation and physico-chemical properties. J. Antibiot. (Tokyo). 44, 1300-1305.

(55) Blin, K., Wolf, T., Chevrette, M. G., Lu, X., Schwalen, C. J., Kautsar, S. A., Suarez Duran, H. G., de los Santos, E. L. C., Kim, H. U., Nave, M., Dickschat, J. S., Mitchell, D. A., Shelest, E., Breitling, R., Takano, E., Lee, S. Y., Weber, T., and Medema, M. H. (2017) antiSMASH 4.0-improvements in chemistry prediction and gene cluster boundary identification. Nucleic Acids Res. 45, W36-W41. 
bioRxiv preprint doi: https://doi.org/10.1101/2020.05.22.111625; this version posted May 25, 2020. The copyright holder for this preprint (which

was not certified by peer review) is the author/funder, who has granted bioRxiv a license to display the preprint in perpetuity. It is made available under aCC-BY-NC-ND 4.0 International license.

(56) Challis, G. L., Ravel, J., and Townsend, C. A. (2000) Predictive, structure-based model of amino acid recognition by nonribosomal peptide synthetase adenylation domains. Chem. Biol. 7, 211-224.

(57) Stachelhaus, T., Mootz, H. D., and Marahiel, M. A. (1999) The specificity-conferring code of adenylation domains in nonribosomal peptide synthetases. Chem. Biol. 6, 493-505.

(58) Rö Ttig, M., Medema, M. H., Blin, K., Weber, T., Rausch, C., and Kohlbacher, O. (2011) NRPSpredictor2-a web server for predicting NRPS adenylation domain specificity. Nucleic Acids Res. 39, W362-W367.

(59) Bachmann, B. O., and Ravel, J. (2009) Chapter 8. Methods for in silico prediction of microbial polyketide and nonribosomal peptide biosynthetic pathways from DNA sequence data, in Methods in Enzymology, pp 181-217.

(60) Rausch, C., Hoof, I., Weber, T., Wohlleben, W., and Huson, D. H. (2007) Phylogenetic analysis of condensation domains in NRPS sheds light on their functional evolution. BMC Evol. Biol. 7, 78.

(61) Nogami, I., Shirafuji, H., and Matsumura, S. (1984) Production of enduracidin and microorganisms therefor. United States Patent Office, Canada.

(62) Lam, K. S., Titus, J. A., Dabrah, T. T., Kimball, D. L., Veitch, J. M., Gustavson, D. R., Compton, B. J., Matson, J. A., Forenza, S., Ross, J., Miller, D., Roach, J., and Beutler, J. (1992) Improved processes for the production and isolation of dynemicin A and large-scale fermentation in a 10000-liter fermentor. J. Ind. Microbiol. 11, 7-12.

(63) Mclntyre, J. J., Bunch, A. W., and Bull, A. T. (1999) Vancomycin production is enhanced in chemostat culture with biomass-recycle. Biotechnol. Bioeng. 62, 576-582.

(64) Menges, R., Muth, G., Wohlleben, W., and Stegmann, E. (2007) The ABC transporter Tba of Amycolatopsis balhimycina is required for efficient export of the glycopeptide antibiotic balhimycin. Appl. Genet. Mol. Biotechnol. $77,125-134$.

(65) Chen, H., Tseng, C. C., Hubbard, B. K., and Walsh, C. T. (2001) Glycopeptide antibiotic biosynthesis: Enzymatic assembly of the dedicated amino acid monomer (S)-3,5-dihydroxyphenylglycine. Proc. Natl. Acad. Sci. U. S. A. $98,14901-14906$.

(66) Cohen, D. R., and Townsend, C. A. (2017) A dual role for a polyketide synthase in dynemicin enediyne and anthraquinone biosynthesis. Nat. Chem. 10, 231-236. 
bioRxiv preprint doi: https://doi.org/10.1101/2020.05.22.111625; this version posted May 25, 2020. The copyright holder for this preprint (which was not certified by peer review) is the author/funder, who has granted bioRxiv a license to display the preprint in perpetuity. It is made available under aCC-BY-NC-ND 4.0 International license.

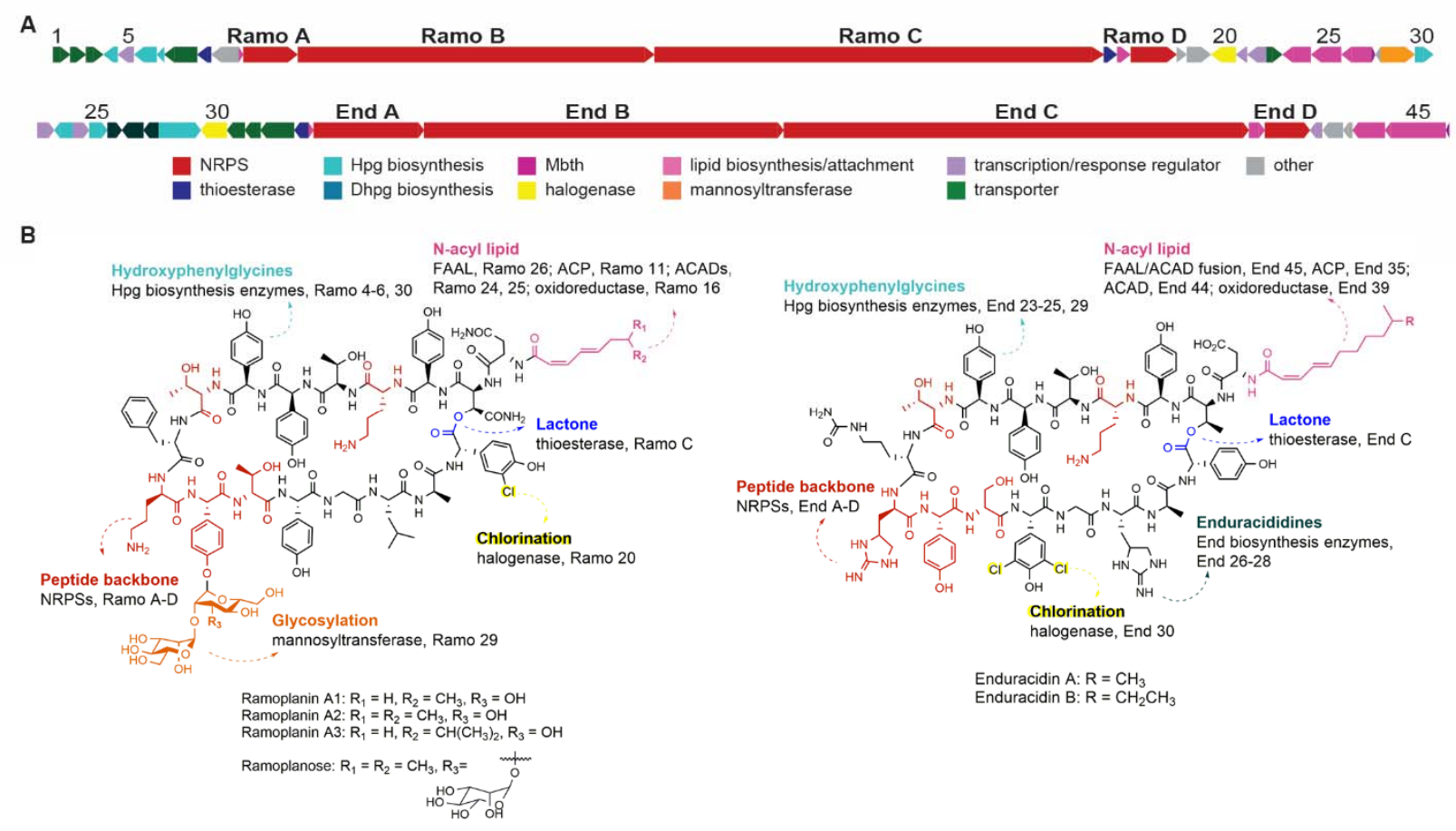

Figure 1. The ramoplanin family antibiotics. A) ORF arrow diagram depicting the defined BGCs from ramoplanin and enduracidin. B) Chemical structures of ramoplanin A2 and enduracidin A. Structural features are colored to coordinate with biosynthetic proteins responsible for their synthesis and incorporation, as shown in the ORF arrow diagram. "Hot spot" residues are in red and have been found to be essential by alanine scanning of ramoplanin, with MIC increases of $>75$-fold and $\mathrm{K}_{\mathrm{d}}$ increases for substrate binding of $>100$-fold. 
bioRxiv preprint doi: https://doi.org/10.1101/2020.05.22.111625; this version posted May 25, 2020. The copyright holder for this preprint (which was not certified by peer review) is the author/funder, who has granted bioRxiv a license to display the preprint in perpetuity. It is made available under aCC-BY-NC-ND 4.0 International license.

\section{A) Targeted SAR-based genome mining}

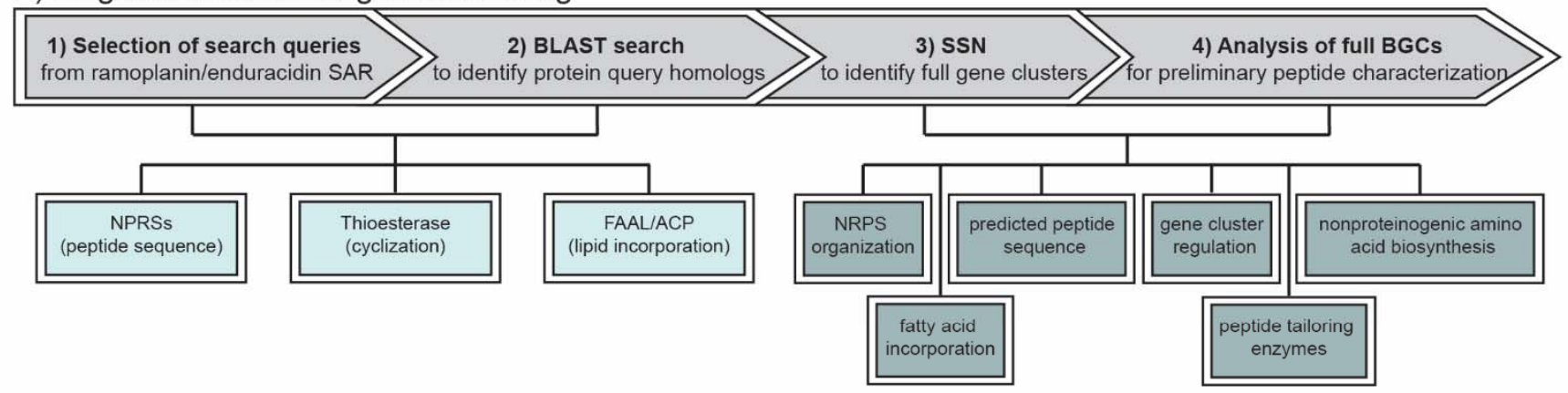

B) Natural product isolation and characterization

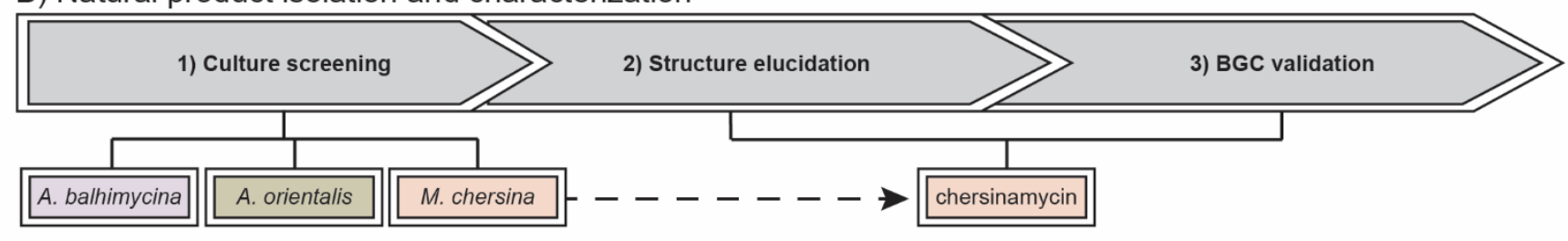

Figure 2. Workflow for the expansion of the ramoplanin family of antibiotics through targeted genome mining. A) Biosynthetic proteins and protein subdomains were selected from the ramoplanin and enduracidin BGCs and used as search queries for a targeted BLASTp search. Initial hits from the BLASTp search were moved forward to identify full gene clusters. B) Bacterial strains identified from SAR-based genome mining were screened for antibiotic production, with full characterization of the new lipoglycodepsipeptide chersinamycin from $M$. chersina. 
bioRxiv preprint doi: https://doi.org/10.1101/2020.05.22.111625; this version posted May 25, 2020. The copyright holder for this preprint (which

was not certified by peer review) is the author/funder, who has granted bioRxiv a license to display the preprint in perpetuity. It is made available under aCC-BY-NC-ND 4.0 International license.

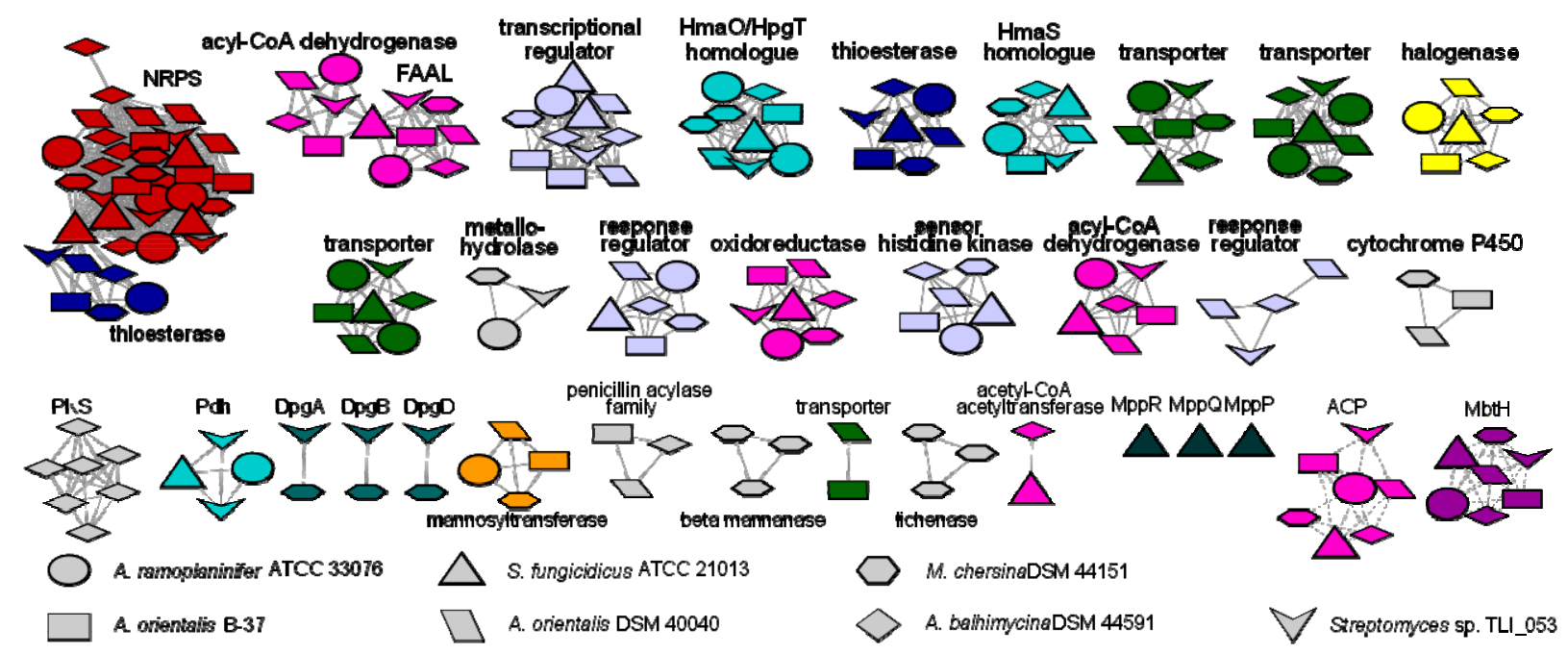

Figure 3. Condensed sequence similarity network for proteins within the BGCs of ramoplanin, enduracidin, and the five new ramoplanin family BGCs identified in this study. The network is assembled with an E value limit of $10^{-5}$ and alignment score of 50 (solid edges) or 25 (dashed edges). 
bioRxiv preprint doi: https://doi.org/10.1101/2020.05.22.111625; this version posted May 25, 2020. The copyright holder for this preprint (which was not certified by peer review) is the author/funder, who has granted bioRxiv a license to display the preprint in perpetuity. It is made available under aCC-BY-NC-ND 4.0 International license.

A

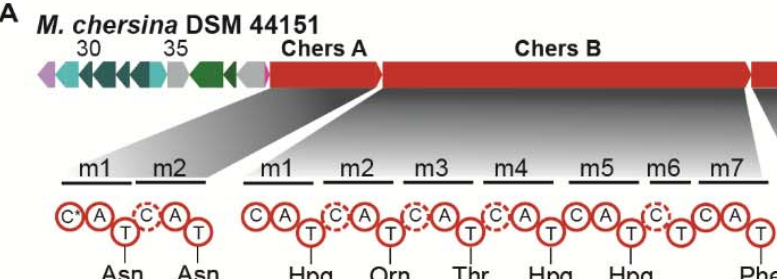

B
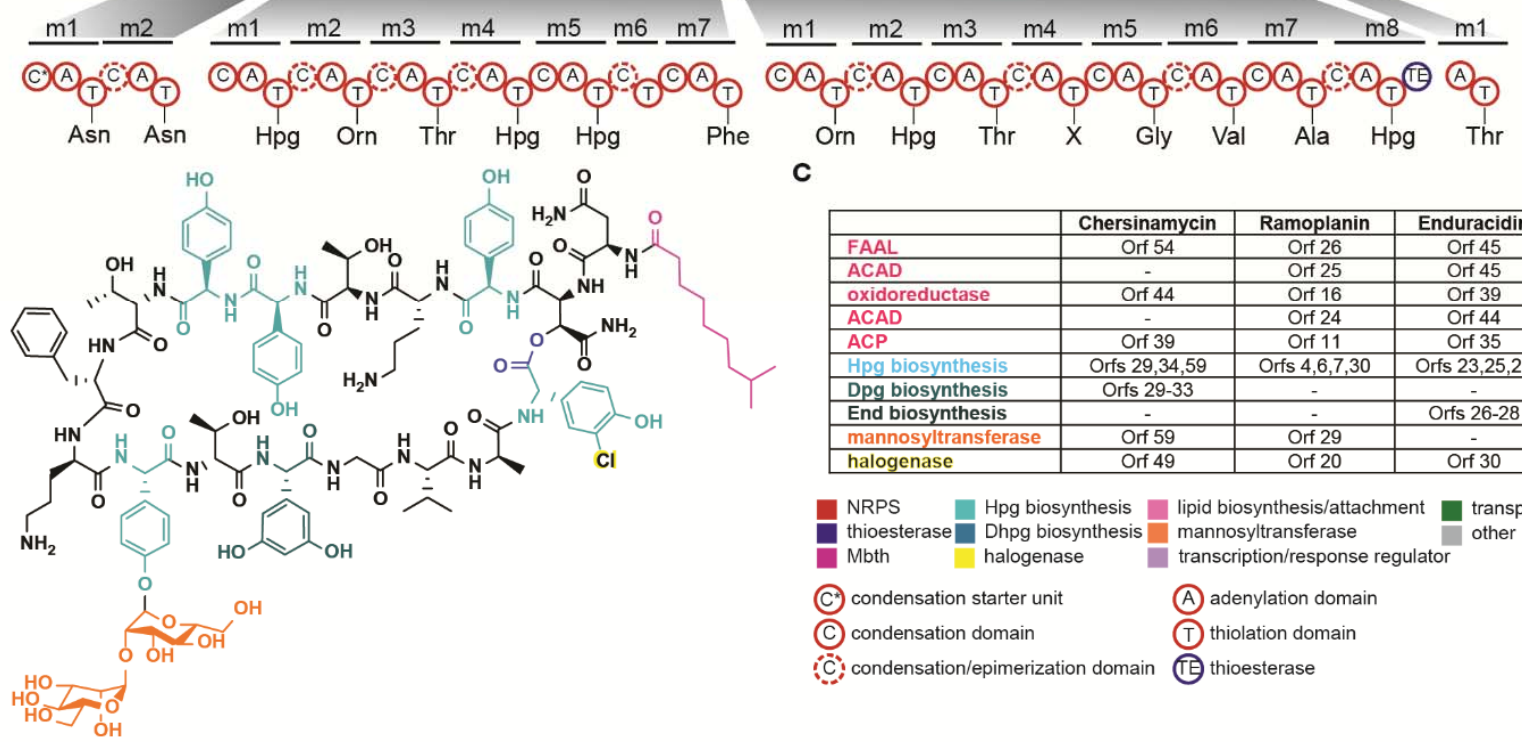

C

\begin{tabular}{|l|c|c|c|}
\hline & Chersinamycin & Ramoplanin & Enduracidin \\
\hline FAAL & Orf 54 & Orf 26 & Orf 45 \\
\hline ACAD & - & Orf 25 & Orf 45 \\
\hline oxidoreductase & Orf 44 & Orf 16 & Orf 39 \\
\hline ACAD & - & Orf 24 & Orf 44 \\
\hline ACP & Orf 39 & Orf 11 & Orf 35 \\
\hline Hpg biosynthesis & Orfs 29,34,59 & Orfs 4,6,7,30 & Orfs 23,25,29 \\
\hline Dpg biosynthesis & Orfs 29-33 & - & - \\
\hline End biosynthesis & - & - & Orfs 26-28 \\
\hline mannosyltransferase & Orf 59 & Orf 29 & - \\
\hline halogenase & Orf 49 & Orf 20 & Orf 30 \\
\hline
\end{tabular}

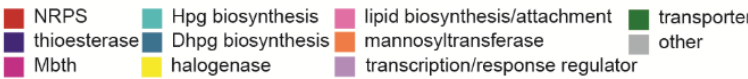

(C) condensation starter unit (A) adenylation domain

(C) condensation domain

(T) thiolation domain

:

Figure 4. Structure and biosynthetic gene cluster of chersinamycin. A) ORF arrow diagram depicting the defined BGC from chersinamycin based on the generated SSN, and architecture of the four NRPSs within the chersinamycin BGC. Predicted amino acids based on adenylation domain specificity sequences are listed. B) Structure of chersinamycin as supported by bioinformatics and classical structure elucidation efforts. Structural motifs are colored according to the corresponding biosynthetic proteins responsible for their synthesis and incorporation. C) Comparison of biosynthetic enzymes found

within the BGCs

of chersinamycin,

ramoplanin,

and

enduracidin. 

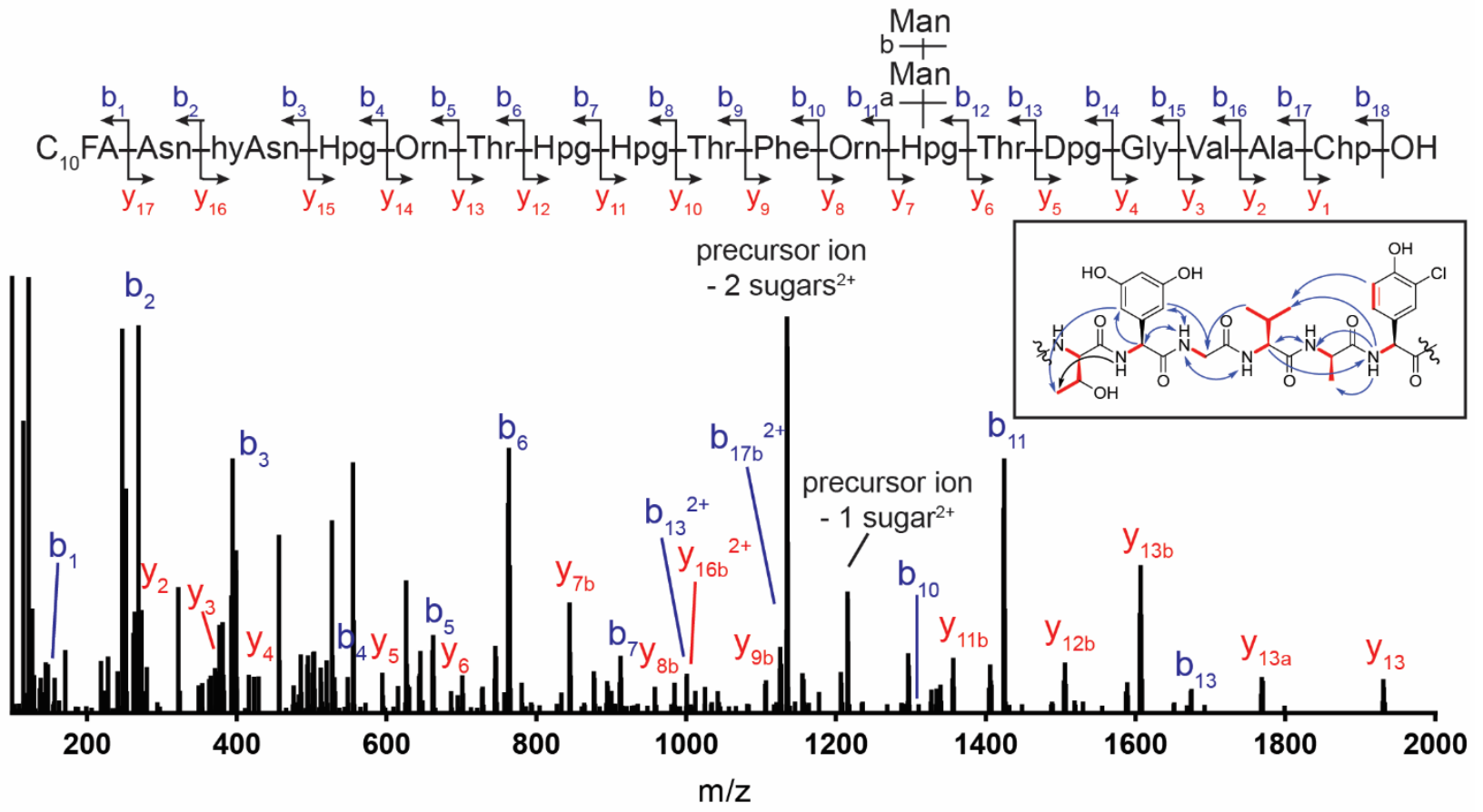

Figure 5. Structural characterization of chersinamycin. The MS/MS spectrum of acyclic chersinamycin is shown with the diagnostic fragmentation pattern of b- (blue) and y-ions (red). Inlaid figure shows COSY/TOCSY (red) and NOESY correlations (blue) for a key region of Dpg13-Chp17, which differs significantly from ramoplanin. Tables of calculated and observed MS/MS ions and full COSY and TOCSY spectra are included in the Supplemental Information. 
bioRxiv preprint doi: https://doi.org/10.1101/2020.05.22.111625; this version posted May 25, 2020. The copyright holder for this preprint (which was not certified by peer review) is the author/funder, who has granted bioRxiv a license to display the preprint in perpetuity. It is made available under aCC-BY-NC-ND 4.0 International license.

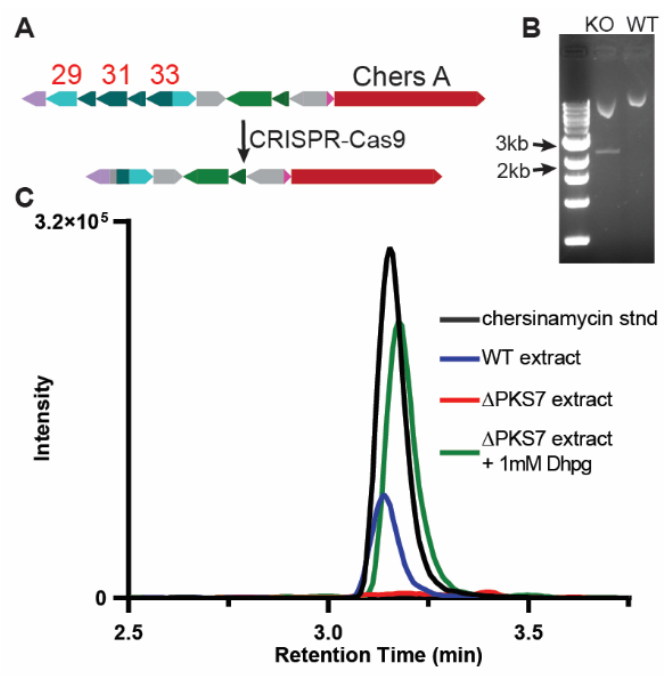

Figure 6. Confirmation of the chersinamycin gene cluster. A) CRISPR-Cas9 facilitated knockout of five genes within the biosynthetic pathway of chersinamycin. The genes have homology to PLP-dependent aminotransferase (Chers 29), DpgD (Chers 30), DpgC (Chers 31), DpgB (Chers 32), and DpgA (Chers 33). B) Confirmation of the knockout region in $\triangle \mathrm{PKS7}$ strain visualized by a $2.2 \mathrm{~kb}$ band generated from PCR of gDNA with primers flanking the knockout region. C) Extracted ion chromatograms for the doubly charged ion species of chersinamycin $(\mathrm{m} / \mathrm{z}=1288)$ in a chersinamycin standard and crude extracts from wild-type M. chersina, $\triangle \mathrm{PKS} 7$, and $\triangle \mathrm{PKS7}$ complemented with $1 \mathrm{mM}$ Dpg. 
bioRxiv preprint doi: https://doi.org/10.1101/2020.05.22.111625; this version posted May 25, 2020. The copyright holder for this preprint (which

was not certified by peer review) is the author/funder, who has granted bioRxiv a license to display the preprint in perpetuity. It is made available under aCC-BY-NC-ND 4.0 International license.

Table 1. MICs of ramoplanin and chersinamycin as measured by broth microdilution assay

\begin{tabular}{|c|c|c|}
\hline & Ramoplanin & Chersinamycin \\
\hline B. subtilis ATCC 6051 & $<0.125 \mu \mathrm{g} \mathrm{mL}^{-1}$ & $<0.125 \mu \mathrm{g} \mathrm{mL}^{-1}$ \\
\hline S. aureus ATCC 25923 & $0.5 \mu \mathrm{gL}^{-1}$ & $2 \mu \mathrm{gL}^{-1}$ \\
\hline E. faecalis ATCC 29212 & $0.5 \mu \mathrm{gL}^{-1}$ & $1 \mu \mathrm{gL}^{-1}$ \\
\hline E. coli ATCC 25922 & $>64 \mu \mathrm{gL}^{-1}$ & $>64 \mu \mathrm{gL}^{-1}$ \\
\hline
\end{tabular}

